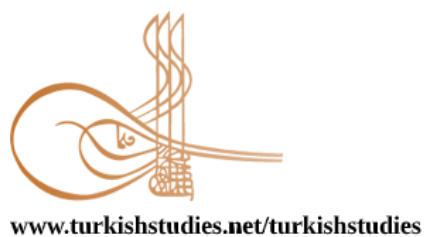

Turkish Studies

www.turkishstudies.net/turkishstudies

eISSN: $1308-2140$

Research Article / Araștırma Makalesi

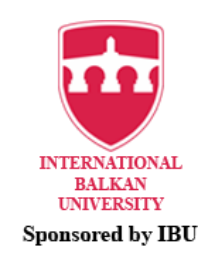

\title{
Mimari Miras ve Koruma Alanında Bir Öncü Eugène Emmanuel Viollet-le-Duc*
}

A Pioneer in Architectural Heritage and Conservation: Eugène Emmanuel Viollet-le-Duc

\author{
Çiler Buket Tosun **
}

\begin{abstract}
Eugène Emmanuel Viollet-le-Duc (1814-1879) - an architect, restorer, researcher, theorist, teacher and writer - was one of the most active and famous architects, first in France and then throughout the world after the second half of the $19^{\text {th }}$ century. The architecture of the Middle Ages in France was researched, documented, conserved and restored by his works. Unlike his contemporaries, he stood against the general attitude of imitating the historical forms in architecture. Instead he used a rational approach to determine the main principles of the structural and geometrical concepts of Gothic architecture through a comprehensive study of the medieval architectural heritage. He believed that the main principles of that period could be combined with a new technology to create an original and national contemporary architecture. His architectural theories spread throughout the world and profoundly influenced the $19^{\text {th }}$ century architecture, the applications of the neo-Gothic architecture, the theories of architectural restoration and the search of a national architecture.This study focuses on the pioneering role of Viollet-le-Duc in the preservation of architectural heritage. First, he is introduced with his life history and professional activities, then his activities in the field of conservation are presented through his approach to architectural heritage, his restoration theory and his selected restorations.
\end{abstract}

Structured Abstract: Eugène Emmanuel Viollet-le-Duc (1814-1879) - an architect, restorer, researcher, theorist, teacher, art historian, writer, geologist, ethnographer, mountaineer and nature fan - was one of the most active and famous architects, first in France and then throughout the world after the second half of the $19^{\text {th }}$ century. The architecture of the Middle Ages in France was researched, documented, conserved and restored by his studies.

Viollet-le-Duc has carried out a comprehensive research of the medieval architectural heritage, with numerous architectural documentations, site surveys and restorations. He started his studies through his surveys first in France then in other European countries such as Italy, England, Germany and Greece; in these surveys he studied the medieval architecture in detail and tried to understand it by making sketches and measured drawings of the buildings. He then published these works in two encyclopedic dictionaries to provide a resource

\footnotetext{
* 'Mimari Miras ve Koruma Alanında Bir Öncü Eugène Emmanuel Viollet-le-Duc' adlı makalemizin içeriğini, Prof. Dr. Mustafa Servet Akpolat'ın danışmanlığında 2008 yılında tamamlanan Eugène Emmanuel Viollet-le-Duc ve Etkileri adlı doktora tezinde ulaşılan verilerin bir bölümü oluşmaktadır. Makalede, literatüre kazandırılan güncel yayınlar olabildiğince kullanılmıș, yeni bir bakış açısının çalışma içeriğine yansıtılmasına özen gösterilmiștir. Bana bu konuyu öneren ve doktora tezimin danışmanlığını yürüten sevgili hocam Prof. Dr. Mustafa Servet Akpolat'a emeği ve her daim desteği için saygılarımla teşekkürlerimi sunuyorum.

** Dr., Hacettepe Üniversitesi, Edebiyat Fakültesi, Sanat Tarihi Bölümü

Dr., Hacettepe Üniversity, Faculty of Letters, Department of History of Art, ORCID 0000-0003-3156-3810

cilerbuket.tosun@hacettepe.edu.tr

Cite as/ Atıf: Tosun, Ç.B. (2021). Mimari miras ve koruma alanında bir öncü Eugène Emmanuel Viollet-le-Duc. Turkish Studies, 16(7), 429-461. https://dx.doi.org/10.7827/TurkishStudies.54792

Received/Geliş: 30 November/Kasım 2021

Accepted/Kabul: 27 December/Aralık 2021

Checked by plagiarism software

Published/Yayın: 31 December/Aralık 2021

CC BY-NC 4.0
} 
for the development of his country's national architecture. One of these is a 10-volume dictionary on medieval architectural heritage -Dictionnaire Raisonné de l'Architecture Française du XIe au XVI Siècle (1854-1868)which is a compendium of Gothic forms and French Gothic details. Ironicaly, it was also the most important source in the application of the neo-Gothic style to architecture, both in his own country and in the world.

In the $19^{\text {th }}$ century historicism, in which history was being researched and written, the history of architecture was also examined with a similar approach. Both the social and individual historical understandings were reflected in architecture by referring to its historical forms, thus a culture was created in which historical forms were reused in the architecture of the century. Unlike his contemporaries, Viollet-leDuc stood against the general attitude of imitating the historical forms in architecture. Throughout his life, he fought against the neo-Classical style that had been embraced under the leadership of Ecole-des Beaux-Art. Instead, through his mentioned studies, he used a rational approach to determine the main principles of the structural and geometrical concepts of Gothic architecture. According to him, the medieval architectural heritage was the only relevant historical period; he believed that the main principles of that period could be combined with a new technology to create an original and national contemporary architecture.

Viollet-le-Duc presented his thoughts in a theoretical book called Entretiens sur l'Architecture. It is possible to read his architectural history narrative, his method of architectural analysis and his understanding of history in this book published in 1863. It was a source of inspiration for the architects of the period. Violletle-Duc also provided architectural education to its readers with both this book and the storybooks he had written for the younger generation to shape their architectural view. His architectural theories spread throughout the world and profoundly influenced the $19^{\text {th }}$ century architecture, the applications of the neo-Gothic architecture, the theories of architectural restoration and the search of a national architecture. The modern architectural theories of the $20^{\text {th }}$ century were also based on his architectural approach.

In his restoration works, it is observed that his first concern was identifying the historical periods of buildings and the alteration processes that buildings went through. Based on his detailed documentations on medieval architectural heritage and the vast knowledge he gained in the process, defining the architectural characteristics and architectural understandings of these periods seems crucial on his decisions of restoration interventions. In his Dictionnaire, he suggested that three triangles ('Egyptian' triangle, equilateral triangle, the isosceles triangle) were the basis of the design of a good 'style' and good 'proportion' in architecture. He decided the additions and/or the removals in the restoration of the buildings accordingly, considering the building to have a 'style' and 'proportion' holisticly after restoration.

Viollet-le-Duc's such 'stylistic recompositions' have been criticized by many researchers who had stated that he did not apply his restoration theory in his restoration works, therefore they lost their original value. It should be noted that Viollet-le-Duc wrote his theories long after his restoration practices, after his thoughts had matured through his restoration experiences; his restoration theory and his restoration works should be evaluated from this perspective.

In this article it is determined that, Viollet-le-Duc applied his scientific method of geometrical and structural analysis to his architectural evaluations and restorations, as well as his architectural designs as exemplified in Eglise St. Gimer. In conclusion, the studies of Viollet-le-Duc are praiseworthy efforts on understanding, documenting and transferring the 'architectural heritage' to future generations. He brought forth the importance of 'architectural heritage' in architectural education, recommending it as a source to identify architectural principles for both national and contemporary (also modern) architecture.

Keywords: Art history, architectural heritage, conservation, theory of restoration, Viollet-le-Duc, national architecture, $19^{\text {th }}$ century architecture

Öz: Eugène Emmanuel Viollet-le-Duc (1814-1879) mimar, mimari restorasyon uzmanı, araştırmac1, kuramc1, eğitimci ve yazar kişiliği ile 19. yüzyılın ikinci yarısından itibaren önce Fransa' da daha sonra da tüm dünyada en etkin ve ünlü mimarlardan biri olmuştur. Onun çalışmalarıyla Fransa'nın Ortaçağ yapıları incelenmiş, belgelenmiş, korunmuş ve restore edilmiştir. Viollet-le-Duc, sayısız mimari belgeleme çalışmaları, yerinde inceleme araştırmaları ve restorasyonları ile ortaçağ mimari mirası üzerine çok kapsamlı bir çalışma gerçekleştirmiş; Gotik mimarlığın strüktürel mantığının ve biçimsel geometrisinin akılcı prensiplerini belirlemeye çalışmıştır. Çağdaşlarının aksine tarihsel biçimleri tekrar eden mimari biçimler üretmeyi değil, bu 
mimari mirasın dehasıyla her çağın ihtiyaç ve teknolojisine göre dönüşebilen; ulusal, akılcı ve modern yapılar yapmayı amaçlamıştır. Yazdığı çok sayıda kitapla, dünya üzerinde yaygınlaşan bu düşünceleri 19. yüzyıl mimarlığında büyük bir etki yaratmış, neo-Gotik mimari uygulamalarına ve özellikle mimari restorasyon kuramına, mimarlıkta ulusal kimlik arayışına ve modern mimarlık kuramlarına kaynak olmuştur. Bu çalışma Viollet-le-Duc'ün öncü olduğu ulusal mimari ve modern mimariye kaynak olan kuramsal yaklaşımlarına değil; 'mimari mirası koruma yaklaşımına' odaklanmaktadır. Viollet-le-Duc öncelikle yaşam öyküsü ile tanıltılmakta, mesleki etkinlikleri çok yönlülüğü ve üretkenliği yönleri ile ele alınmaktadır. Mimari miras ve korumacılık alanındaki etkin rolü, bu alandaki etkinlikleri, seçilmiş restorasyon uygulamaları ve mimari restorasyon kuramı üzerinden sunulmaktadır. Viollet-le-Duc'ün mimari mirasa yaklaşımının ve koruma anlayışının ortaya konulması ve değerlendirilmesi amaçlanmaktadır.

Anahtar Kelimeler: Sanat tarihi, mimari miras, koruma, restorasyon kuram1,Viollet-le-Duc, ulusal mimari, 19. yüzy1l mimarisi

\section{Giriș}

Eugène Emmanuel Viollet-le-Duc (1814-1879) mimari etkinlikleriyle ve mimarlık üzerine düşünceleriyle 19. yüzyılın ikinci yarısından itibaren ilk olarak Fransa'da mimarlık ortamında öne çıkmış daha sonra mimar, restorasyon uzmanı, araştırmacı, kuramcı ve yazar kişiliği ile tüm dünyada etkili olmuştur.

Onun çalışmalarıyla Fransa'nın Ortaçağ yapıları incelenmiş, belgelenmiş, korunmuş ve restore edilmiştir. Viollet-le-Duc sayısız mimari belgeleme çalışmaları, yerinde inceleme araştırmaları ve restorasyonları ile ortaçağ mimari mirası üzerine çok kapsamlı bir çalışma gerçekleştirmiş̧tir.

Tarihin araştırıldığ ve yazıldığı 19. yüzyıl historisizmi içinde; mimarlık tarihi de benzer bir yaklaşımla incelenmiştir. Hem toplumsal hem de bireysel tarih anlayışlarının mimariye, tarihsel biçimlerine atıfta bulunularak yansıdığı; böylece tarihsel biçimlerin yüzyılın mimarisinde tekrar kullanıldığı bir yapı kültürünün oluştuğu görülmüsstür. Viollet-le-Duc, çağdaşlarının aksine tarihsel biçimleri tekrar eden mimari biçimleri üretmeyi değil, bu mimari mirasın dehasıyla her çağın ihtiyaç ve teknolojisine göre dönüşebilen; ulusal, akılcı ve modern yapılar yapmayı amaçlamıştır.

Viollet-le-Duc yaşadığı dönem boyunca Fransa'nın tüm mimarlık ve restorasyon kurumlarında merkezi ve etkin roller üstlenmiş, 200'ü aşkın yapının eskiz ve/veya rölöve çizimlerini, 70'e yakın yapının restorasyonunu gerçekleştirmiş, büyük bir çoğunluğunda da mimari müdahalelerde bulunmuştur. Viollet-le-Duc Fransa dişındaki ülkelerden Almanya, Belçika, Hollanda, İsveç, İtalya, İngiltere, Avusturya ve Çekoslovakya'da da çeşitli yapıların rölöve ve restorasyon projelerini yapmış; İsveç'de bir şato, bir şapel, bir anıt ve kendisi için bir ev inşa etmiştir. Restorasyonunu yapmış olduğu katedral, kilise, şato, ve konut yapıları için heykeller, mobilyalar, vitraylar tasarlamış, bunun yanı sıra 16 dini yapı, 7 kamu yapısı, 26 konut yapısı, 23 anıt ve imparatorluk için tren vagonu tasarlamıştır ${ }^{1}$. Viollet-le-Duc hayatı boyunca her yere çizim defteri ve kalemiyle gitmiş, gördüğ̈̈ her yapıyı çizmiş, ölümünden sonra ise tasarım ve restorasyonlarına ilişkin yaptığı çizimleri, başta Fransa olmak üzere İtalya, İngiltere, İsveç ve Amerika'da düzenlenen 13 sergiyle meraklılarına sunulmuştur.

\footnotetext{
${ }^{1}$ Viollet-le-Duc'ün mimarlık etkinlikleri için bkz. (Tosun, 2008)
} 


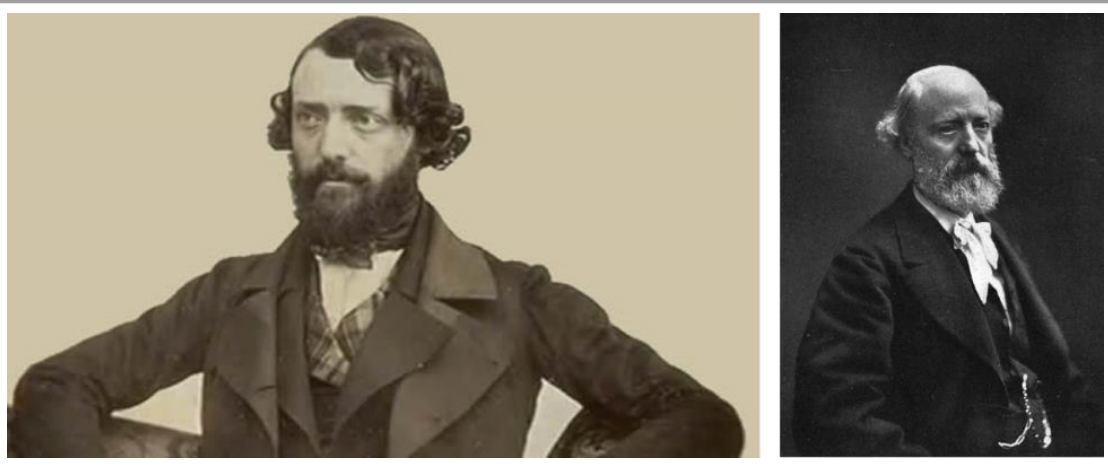

Resim 1: Eugène Emmanuel Viollet-le-Duc (Foucart vd., 1980)

Viollet-le-Duc, sadece Fransa'da ortaçağ ile ilgilenen ilk mimar ve ilk restorasyon uzmanı olarak tanınmamış, onun 19. yüzyılın başında romantik akımın, akılcı mimarlığın ve eleştiri çağına geçiş döneminin öncüsü olduğu da belirtilmiştir (Erder, 1972, s. 5-6).

\section{Yaşam Öyküsü}

Eugène Emmanuel Viollet-le-Duc, sözü geçen ve sanatla ilgili bir ailenin çocuğu olarak 27 Ocak 1814'de Paris'te doğar. Sanata meraklı olan babası Emmanuel Viollet-le-Duc (1781-1857), Savunma Bakanlığı'nda çalışmaktadır ve devrim sırasında birçok özel kütüphaneden dağıtılmış olan 16. yüzyıl ve öncesi Fransız yazarlarının kitaplarını toplayarak oluşturduğu özel bir koleksiyonun sahibidir. Annesi ise Odéon ve Hotel de Salm'ın inşaasını üstlenmiş başarılı bir mütahitin kızıdır ve her cuma Viollet-le-Duc'ün doğduğu Rue Chabanais'deki konutlarının birinci katında dönemin sanat çevresinden ünlü isimlerin katıldığı seçkin salon toplantıları düzenlemektedir. Aynı konutun dördüncü katında yaşayan dayısı Etienne-Jean Delécluze (1781-1863) ise sanat eleştirmeni ve ressamdır. Ressam Jacques Louis David'in (1748-1825) öğrencisi olan Delécluze, Journal des Débats da sanat üzerine eleştiri yazıları yazmıştır. Pazar günleri öğleden sonra, saat 2 ile 5 arasında özellikle dönemin romantizm akımının ünlü isimlerini ağırladığı belirtilmektedir. Viollet-le-Duc'ün hem annesinin hem de dayısının düzenlediği bu toplantıların pek çok ünlü misafiri vardır. Bunlar arasında özellikle; realizmin öncülerinden kabul edilen Kırmızı ve Siyah (1830) ve Parma Manastırı (1839) romanları ile tanıdığımız Marie Henri Beyle Stendal (1783-1842), yazdığı Karmen (1845) romanıyla anılan dönemin etkin tarihçi ve arkeoloğu Prosper Mérimée (1803-1870), 1830'a kadar güzel sanatlar başkanlığı yapmış olan politikacı ve gazeteci Emile de Girardin (1802-1881), Globe gazetesi yazarlarından ve Victor Hugo'ya yakınlığı ile de bilinen dönemin ünlü edebiyat tarihçisi ve eleştirmeni Charles Augustin Sainte-Beuve (1804-1869), politikacı Ludovic Vitet (1802-1873), politika üzerine yazılarıyla tanınan Paul-Louis Courier (1773-1825), mimar Jean-Jacques-Marie Huvé (1783-1852) ve mimar Achille François-René Leclère (1785-1853), heykeltraş Desboeuf, ressam Raymond Monvoisin (1790-1870), jeolog Alexandre Brongniart (1770-1847) ve elektromagnetizmayı ilk bulan kişi olan ünlü fizikçi André-Marie Ampère (1775-1839) gibi kişiler bu toplantıların müdavimi olarak ortaya çıkar (Viollet-le-Duc, 1980a, s. 31; Erder, 1972, s. 65; Summerson, 1968, s. 135-136; Pevsner, 1972, s. 194-195, Jokilehto, 1999, s. 140). Viollet-le-Duc evlerinde sanat çevresine verilen toplantılar sayesinde, daha küçük yaşta dönemin ünlü sanatçı ve düşünürlerinin görüşlerini dinleme şansına sahip olarak büyümüştür.

Eugène 9-10 yaşında iken küçük kardeşi Adolphe ile birlikte cumhuriyetçi ve laik olduğu için dayısı tarafından seçilmiş olan Fontenay-aux-Roses yakınındaki bir yatılı okula gönderilmiştir. ${ }^{2}$ Yeğenlerinin eğitimi ile bizzat ilgilenen dayısı Delécluze, eğitimleri sırasında onları yanlız bırakmamış ve Fontenay'a taşınmıştır. Delécluze, Viollet-le-Duc'ün sadece alacağı eğitime yönelik kararlarda değil, kişiliğinin ve dünya görüşünün gelişiminde de önemli bir rol oynamış; onun sadece

\footnotetext{
${ }^{2}$ Pevsner, Viollet-le-Duc'ün Lycée Condorcet’de eğitim aldığını belirtmektedir (1972, s. 194)
} 
dayısı değil, akıl hocası ve kendini en yakın hissettiği kişi olmuştur. Viollet-le-Duc'e doğanın gözlemlenmesi ve kopyalanmasına dayanan bir resim eğitimi veren Delécluze filozof-ressam olarak adlandırdığı yine David'in öğrencilerinden biri olan Nicolas Paillot de Montabert (1771-1849)'in düşüncelerini benimsemiş ve Viollet-le-Duc'e de benimsetmiştir. Nicolas Paillot de Montabert, 1828 'de yayınlanan on ciltlik Traité Complet de la Peinture (Resim Üzerine İnceleme) kitabının yazarıdır. Montabert bu kitabında sanatın fikir ve hislere değil, mantıklı ve bilimsel nedenlere dayanması, bu nedenle de sanatçılara bir takım kurallar sunulması gerektiğini savunmaktadır. Kitabında Ecole des Beaux-Arts eğitimini eleştirmekte ve sanatın ana prensiplerine geri dönülerek yeni bir kuram geliştirilmesi gerektiğini anlatmaktadır. Montabert'e göre, anatomi ve geometri sanata bilimsel bir nitelik kazandırmaktadır. Bu nedenle, çizimi yapılacak her nesnenin öncelikle doğal geometrisinin kavranmas1 gerekmektedir (Bressani, 2000a, s. 130-131). Viollet-le-Duc'ün bu düşünceleri tamamen benimsemiş olduğunu söylemek yanlış olmayacaktır. ${ }^{3}$

Viollet-le-Duc 11 yaşında başladığı Bourbon Koleji (Collège de Bourbon)'ndeki eğitiminden 16 yaşında olgunluk sınavını (baccalauréat) almıştır. ${ }^{4} 1827$ 'de Valenion'da küçük bir ev inşa eden Viollet-le-Duc, Ecole des Beaux-Arts (Güzel Sanatlar Okulu)'da eğitim görmeyi reddetmiş ve mimarlık kariyerine 1830 'da henüz 16 yaşında iken mimarlık ofisinde çalışarak başlamıştır. İlk olarak ailesinin ve Delécluze'un yakın dostu olan ve Madeleine Kilisesi (18281842)'nin yapımından sorumlu olan mimar Jean Huvé'ün yanında, daha sonra da mimar Achille Leclère'in yanında çalışmıştır (Viollet-le-Duc, 1980a, s. 30-31; Bercé, 1996, s. 594).5

Babasının 1830 yılında Paris'deki Tuileries sarayına yönetici olarak atanmasıyla ailecek buraya taşınmışlardır. 1831 yılında dayısı Delécluze ile birlikte ilk gezisine çıkmış, 21 Temmuz-20 Ekim tarihleri arasında Fransa'nın güney kentlerini gezmiştir. 1832 yılında annesinin vefatı Violletle-Duc'ü çok etkilemiş, yaşadığ bu üzüntüyle kendini okumaya, gezmeye, yazmaya ve çizim yapmaya vermiştir. Bu dönemde aşık olduğu genç kızın ailesi yaşı küçük olduğu için Viollet-leDuc'ü kabul etmediklerinde üzüntüsünü unutmak için Fransa'nın kuzey kentlerine tek başına 25 günlük bir seyahat yapmıştır. Viollet-le-Duc ondokuz yaşında bir kez daha aşık olmuş ve Fransa'da 4 Mayıs-15 Eylül 1833 tarihleri arasında yaptığı seyahatlerin üçüncüsünde kendisine eşlik eden müzisyen Emille Millet'nin evinde tanışmış olduğu Elisabeth Tempier ile 1834'de evlenmiştir (Viollet-le-Duc, 1980a, s. 33-34; Summerson, 1963, s.137).

Aynı yıl Viollet-le-Duc, 1851'e kadar ders vereceği, Ecole Gratuite de Dessin (Parasız Tasarım Okulu)'nde süsleme ve kompozisyon hocası olarak dersler vermeye başlamış, aynı zamanda ülke içi gezilerine de devam etmiştir. ${ }^{6}$ Eşi ve erkek kardeşi Adolphe ile birlikte bir haftalı̆̆ına Normandiya'ya seyahat eden Viollet-le-Duc, ertesi yıl da gravür sanatçısı Léon Gaucherel (18161886) $)^{7}$ ile birlikte tekrar 1 aylık bir Normandiya seyahatı yapmıştır. Viollet-le-Duc ilk yurtdışı

\footnotetext{
${ }^{3}$ Viollet-le-Duc'ün bilimsel yaklaşımında Montabert'in yanı sıra dönemin ünlü Fransız bilim adamlarından jeolog Jacques Boucher de Perthes (1788-1868) ve anatomi üzerine çalışmaları bulunan zoolog Georges Cuvier (1769-1832) ile doğabilimci Etienne Geoffroy-Saint Hilaire'in (1772-1844) de önemli bir etkisi olmuş; Viollet-le-Duc Entretiens kitabında birçok kez “önemli olan şudur; Mimarlık tarihi bilgisini titiz bir metotla uygulamak için Descartes'ın dört temel unsurundan daha iyi bir uygulama göremiyorum" görüşünü yineleyerek bilimsel yaklaşımında Descartes'ın yöntemini benimsediğini belirtmiştir (Middleton, 1998, s. 764; Mead, 1983, s. 525).

${ }^{4}$ Paris'te o dönemde yatılı olmayan iki liseden biridir. 1800'de Bonaparte Lisesi olarak kurulan lisenin adı 1814'de Bourbon Kraliyet Koleji olarak değişmiştir (Stanford Paris Guide, 1862, s. 135).

${ }^{5}$ Bahsedilen her iki mimar da ressam David gibi, 1804-1815 yılları arasında Fransız İmparatorluğu'na hükmeden 1. Napoléon'un (Napoléon Bonaparte 1769-1821) beğenisini yansitan, İmparatorluk üslubunun uygulayıcılarından olan mimar Charles Percier'in (1764-1838) Ecole des Beaux-Arts'daki atölyesinden mezun olmuşlardır.

${ }^{6}$ Académie de Peinture, Sculpture et Architecture (Valenciennes)'e (Resim, Heykel ve Mimarlık Akademisi) bağlı olarak 1766 'da kurulan ve Petite Ecole (Küçük Okul) olarak da bilinen okulun adı 1877'de École des Arts Décoratifs (Süsleme Sanatı Okulu) olarak değişmiştir.

${ }^{7}$ Ecole Gratiute de Dessin'de Viollet-le-Duc'ün öğrencisi olan Gaucherel, daha sonra Viollet-le-Duc'ün yayınlarının gravür sanatçısı olarak çalışmıştır.
} 
seyahati olan İtalya gezisini yine Gaucherel ile birlikte yapmış, eşini ve 1835 'de doğmuş olan oğlu Eugéne Louis'yi Paris'te bırakarak, 12 Mart 1836- 1 Eylül 1837 tarihleri arasında Napoli, Sicilya, Floransa, Assisi, Bolonya, Venedik, Perugia, Siena, Pisa, Pompei ve Roma'da mimari eserleri yerinde incelemiştir. Roma'da bulunduğu 6 ay içinde Fransız Akademisi Villa Medici'de yönetici olan Jean Auguste Dominique Ingres (1780-1867) ile de tanışmıştır. Birçok detaylı eskiz ve rölöve çizimleriyle ${ }^{8}$ Paris'e dönen Viollet-le-Duc'ün gezi sırasında yapmış olduğu 221 adet çizim, 18381845 yılları arasında Baron Isidore Justin Séverin Taylor (1789-1879)'ın editörlügünü yaptığ1 Voyages Pittoresques et Romantiques dans l'Ancienne France (Antik Fransa'da Romantik ve Pitoresk Görünümler)'de yayınlanmıştır. Viollet-le-Duc, Paris'e döndükten sonra babası, eşi ve çocuğu ile birlikte Tuilerise Palace'dan ayrılarak Rivoli caddesi 16 numaralı eve taşınmıştır. 1838'de ikinci çocuğu olan kızı Marie-Sophie doğmuştur (Viollet-le-Duc, 1980a, s. 35).

Viollet-le-Duc İtalya seyahatinin ardından, Paris'e döndükten sonra, 1838 'de, daha önce yanında çalışmış olduğunu belirttiğimiz, mimar Achille Leclère'in başkanı olduğu Conseil des Bâtiments Civils'de (Resmi Yapılar Konseyi) ${ }^{9}$; 1839 'da da dayısı Delécluze'un dostu Prosper Mérimée'nin başkanı olduğu Commission des Monuments Historiques'de (Tarihi Anıtlar Komisyonu) görevlendirilmiştir (Viollet-le-Duc, 1980a, s. 35; Pevsner, 1972, s. 195).

Konumuzla ilgili olması nedeniyle, bahsedilen kurumların Fransa' daki kentleşme ve mimari yapı faaliyetlerinde ne kadar yetkin ve etkin olduğunu burada kısaca anlatmak yararlı olacaktır. Viollet-le-Duc'ün yaşamı boyunca ülkesi Fransa'nın yönetiminde köklü değişimler olmuş, her yönetim kendi ideolojisini mimarlık üzerinden ifade etmeyi amaçlamıştır. ${ }^{10}$ Değişen yönetimlerin beğenileri farklılaşırken, XIV. Louis (1638-1715) rejiminden itibaren Paris'in devleti temsil eden anıtsal bir mimari biçimlenmeyle yapılandırılması amacı, ortak bir tavır olmuştur. ${ }^{11}$ Viollet-leDuc'ün mimari çalışmalarıyla etkin olduğu 1830-1870 yılları arasındaki dönemde ise, Fransa'daki mimari etkinlikler daha önce hiç olmadığı kadar sıkı bir şekilde devletin kontrolü altında yürütülmüştür. Tüm yapılar; anıt, tiyatrolar, kiliseler, saray yapıları, enstitüler, hapishaneler, kütüphaneler ve tarihi yapılara ilişkin müdahaleler devletin çeşitli kurumlarının ${ }^{12}$ kontrolünde, bu kurumlarda çalışan mimarlar ${ }^{13}$ tarafından, devletin gücünü ve karakterini yansıtacak şekilde biçimlendirilmişlerdir. Devletin tek mimarlık eğitim kurumu olan Ecole des Beaux-Art da, devletin tüm sanatsal faaliyetlerini yöneten Académie des Beaux-Art'in (Güzel Sanatlar Akademisi) belirlemiş olduğu öğretiyi vermektedir. ${ }^{14}$ Conseil des Bâtiments Civils, Fransa'nın tüm yapı

\footnotetext{
${ }^{8}$ Packard Viollet-le-Duc'ün 450 çizimle döndüğünü belirtmektedir (1989, s. 254).

${ }^{9}$ Conseil des Bâtiments Civils’ $i$ Haluk Togay “Fransız Sivil Binalar Konseyi” olarak Türkçe'ye çevirmiştir (1980a, s. 111) C. Erder, ise "Bayındırlık Bakanlığı Resmi Yapılar Konseyi” olarak Türkçe’ye çevirmiştir (1972, s. 65). Türkçe çevirisinin 'Resmi Yapılar Konseyi' olmasının daha doğru olacağı düşünülmüştür.

${ }^{10}$ Ülke yönetimindeki değişimler sırasıyla şu şekilde gelişmiştir : Fransa'nın son kralı olan Louis Philippe'nin (1773-1850) yönetimindeki Temmuz Monarşisi (1830-1848), İkinci Cumhuriyet Dönemi (1848-1852), III. Napoléon'un (Charles Louis Napoleon Bonaparte 1808-1873) yönetiminde İkinci İmparatorluk dönemi (1852-1870) ve Üçüncü Cumhuriyet Dönemi (1870-1940).

11 Örneğin III.Napoleon Paris'i çarşılar, çeşmeler, bulvarlar, köprüler, okullar, hapishane, mezarlık ve Borsa yapısı ile donatan bir tasarım hazırlamıştır (Van Zanten, 1994, s. 136; Jacques, 1982, s. 62).

${ }_{12}$ Bahsedilen kurumlar Conseil des Bâtiments Civils, Travaux de Paris (Paris İmar Müdürlüğü), Palais Impériaux (İmparatorluk Saray1), Conseil des Edifices Diocésains (Dini Yapılar Konseyi), Commission des Monuments Historiques (Tarihi Anıtlar Komisyonu)'dir. Ayrıntılı bilgi için bkz. (Van Zanten, 1994)

${ }^{13} \mathrm{Bu}$ dönemde hem eğitim alanındaki hem de mimari uygulama alanındaki en ünlü mimarların Jean-Nicolas-Louis Durand (1760-1834), Charles Percier (1764-1838), P.-F.-L. Fontaine (1762-1853), Quatremère de Quincy (1755-1849), Félix Duban (1796-1871), Henri Labrouste (1801-1875), Louis Duc (1802-1879), Léon Vaudoyer (1803-1872), Victor Baltard (1805-1874), E.E.Viollet-le-Duc ve Charles Garnier (1825-1898) olduğu belirtilmektedir (Van Zanten, 1994, s. 47).

${ }^{14} 1795$ 'de kurulan Institut de France (Fransa Enstitüsü)'a bağlı beş akademiden biri olan Académie des Beaux-Art, 1816 'da kurulmuş, 40 üyeden oluşan bir kuruldur. Akademik düzenden sorumlu olan Akademinin genel sekreteri, A.C. Quatremère de Quincy (1755-1849), Klasik mimarlığı dönemin mimari biçimlenişine kaynak olarak belirlemiştir. Ortaçağ mimarlığını ise kuralsız ve tuhaf olarak nitendirerek tamamen reddetmiştir. 1836'da emekliye ayrılınca yerine geçen RaoulRochette (1790-1854) de onun görüşlerini benimsemişsir (Levine, 1982a, s. 67; Pevsner, 1972, s. 197).
} 
faaliyetlerinden ve tüm kentlerin planlanmasından sorumlu olan kurumudur. Bütün projeler öncelikle bu konseye sunulmakta; proje, eleştiri ve öneriler doğrultusunda konsey tarafindan değiştirilebilmektedir (Van Zanten, 1994, s. 46-51). ${ }^{15}$

Commission des Monuments Historiques ise bahsettiğimiz dönemde tarihi anıtların belgelenmesi, korunması, restore edilmesi amacıyla kurulan devlete bağlı yeni bir kurumdur. Victor Hugo'nun, 1831'de yayınlanan, kahramanı Paris'deki Notre-Dame Katedrali olan ünlü NotreDame'ın Kamburu isimli, eserinin yankılarıyla Ortaçağ yapıları ilgi odağı olmuştur. Ulusal birliğin vurgulaması ve ulusal belleğin yapılandırılması arzusunda olan Fransa Kralı Phillipe'in de yönetimiyle, Ortaçağ dönemine ait anıtların belgelenmesi ve rölövelerinin çıkarılması için, Arcisse de Caumont (1801-1873)'nun çabalar1 ${ }^{16}$ sonucunda kültür bakanı François Pierre Guillaume Guizot (1787-1874) önderliğinde 1833'de Société Française d'Archéologie (Fransız Arkeoloji Derneği) ve Société pour la Conservation des Monuments (Anıtları Koruma Derneği) kurulmuştur. Bu derneklerin kurumlaşmasıyla 1837 'de tarihi anıtların restorasyon projelerinden sorumlu olan Commission des Monuments Historiques kurulur (Van Zanten, 1994, s. 61; Pevsner, 1972, s. 195; Bercé, 1996, s. 594).

1834'de Prosper Mérimée Société pour la Conservation des Monuments'in bașkanı olmuştur. ${ }^{17}$ Prosper Mérimée, Vézelay'daki Madeleine manastırının restorasyon işini; mimar A.N. Caristie ve Duban, biri sağlığının iyi olmadığını, diğeri ise yapının kurtarılmasının olanaksız olduğunu belirterek kabul etmeyince; Viollet-le-Duc'e vermiştir. 1840'da Vézelay'daki Madelaine Kilisesi'nde ilk restorasyon çalışmaları ile Viollet-le-Duc; hayatının sonuna kadar sürdüreceği, Fransa'nın ortaçağ yapılarının restorasyonlarında önemli bir rol üstlendiği; bu kurumdaki kariyerine başlamıştır. Aynı zamanda, Duban'ın yönetiminde, Paris'deki Sainte-Chapelle'in restorasyonunu Jean-Baptiste-Antoine Lassus (1807-57) ile birlikte sürdürmüştür (Pevsner 1972, s. 195,197; Summerson, 1963, s. 137). ${ }^{18}$

A.N. Didron (1806-1867) tarafından kurulan ve benimsediği görüşlerle Ecole des BeauxArts karşıtı bir tutumu olan Annales Archéologiques (Arkeoloji Yılllı̆̆ 1 ) isimli gazetenin ${ }^{19} 1844$ 'de yayınlanan ilk sayısındaki makalesiyle Viollet-le-Duc, mimarlık üzerine düşüncelerini de yazmaya başlamıştır.

Viollet-le-Duc'ün, Paris mimarlık ortamında adının duyulması ise Lassus ile birlikte 1842' de katıldıkları Paris Notre-Dame Katedrali restorasyonu proje yarışmasını kazanması ile olmuştur

15 1791'de kurulmuştur. Académie des Beaux-Art üyeleri de bu konseyde görevlendirilmişlerdir. Özellikle 'Büyük Roma Ödülü’nü kazanan mimarlar, Roma'dan döndükten sonra, bu konseyde görev almaktadırlar (Van Zanten, 1994, s. 47-51). 16 1814'de yayınlanmaya başlanan İngiltere'nin Antik Katedralleri'ni konu alan John Britton (1771-1857)'un 14 ciltlik çalışmasından ve Augustus Welby Nortmore Pugin'in (1812-1852) Gotik mimarlık üzerine 1821'de yayınlanan çalışmasından etkilenen Arcisse de Caumont (1801-1873) 1823'de Société des Antiquaires de Normandie (Normandiya Anıtlar Birliği)'yi kurmuş ve 1830'da Norman Mimarlığı üzerine önemli bir çalışma yayınlamıştır (Pevsner, 1972, s. 195).

${ }^{17}$ Société pour la Conservation des Monuments'ın ilk başkanı Ludovic Vitet, üyeleri ise arkeolog ve tarihi eser uzmanları Baron Justin Taylor (1789-1879), Auguste Leprevost (1787-1848), Charles Lenormant (1802-1859) ve Kont Montesquiou, mimar Augustin-Nicolas Caristie (1783-1862) ve Ecole des Beaux-Arts binasının ünlü mimarı Félix Duban (17891870)'dir.

${ }^{18}$ Fransız neo-Gotik mimarlık savunucularından Lassus, Ecole des Beaux Art'da eğitim almış, eğitiminin son senesinde (1830) Henri Labrouste'un öğrencisi olmuştur. Önemli restorasyon çalışmaları yapmış olan Lassus, Viollet-le-Duc'ün yanında mimarlık tarihinde öne çıkamamış, ancak yaşadığı dönemde mimarlık ortamında önemli bir yere sahip olmuştur. Lassus'un çalışmalarına ilişkin ayrıntılı bilgi için bkz. (Mead, 1983, s. 523-525; Middleton, 1982, s. 456-457)

${ }^{19}$ Bahsedilen gazetenin, 1840'da César Daly (1809-1893) tarafindan kurulan Revue Générale de l'Architecture (Mimarlığa Genel Bakış) isimli gazete ile birlikte, akademinin neo-Klasik mimarlık anlayışı ve mimari uygulamaları yanı sıra neoGotik mimarlık düşüncelerine yönelik yayınlanan eleştirel yazılarıyla kamu oyunda tartışma ortamı oluşmasında ve Paris'de 1848'de neo-Klasik uygulamaların başlamasında etkin bir yeri olmuştur (Boucher-Rivalain, 1998, s. 145-152). Bu iki gazatedeki yayınlanan yazılarla 1845-1846 yılları arasında Ecole des Beaux-Arts hocalarının neo-Kalsik mimarlığı, ile Viollet-le-Duc ve Lassus önderliğindeki yazarların ise neo-Gotik mimarlığı savundukları, birbirlerine karşı kimi zaman sert tutum ve ifadelerin de yeraldığı yazılar için bkz. (Pevsner, 1972, s. 197-203). 
(Resim: 10-11). 1845'de başlayan Notre-Dame Katedrali restorasyon çalışmaları ile artık tanınan bir mimar olan Viollet-le-Duc, kendine Marché-St-Honoré Sokağ 4 numaralı dairede bir mimarlık ofisi açmıştır. 1864 yılında tamamlanacak olan Notre-Dame Katedrali restorasyon çalışmalarına devam ederken; yapımı 1867 yılına kadar sürecek olan Carcassone'daki St-Nazaire Kilisesi tasarımını ve Berlin Sokağı'ndaki Courmont Evi'nin tasarımını yapmıştır (Resim 2).

Viollet-le-Duc, mimarlık ofisinde yoğun mimarlık etkinliklerini yürütürken, LouisNapoléon Bonaparte'ın Cumhuriyet yönetiminin başına getirildiği 1848 yılında Conseil des Edifices Diocésains (Dini Yapılar Konseyi) üyesi olmuş ve babasından ayrı ailesi ile birlikte yaşayacağı Vemeuil sokağı 9 numaralı daireye taşınmıştır (Packard, 1989, s. 253).

1849 yılında Amiens Katedrali restorasyon projesine başlayan Viollet-le-Duc, 1850'de Prosper Mérimée ile birlikte bir aylık İngiltere seyahatine çıkmıştır. Oxford, Londra, Cambridge, Ely, Lincoln, Canterbury, Hampton, Winchester, Boston, Peterborough kentlerini gezdiği 26 Mayıs21 Haziran tarihleri arasında gerçekleşen bu seyahati sırasında, arkeolog John Henry Parker (18061884)'la da tanışmışır. ${ }^{20}$ Aynı yıl, Napoléon'un anıt mezarı projesini Viollet-le-Duc'ün yakın arkadaşı Lassus'un da hocası olan Ecole des Beaux-Arts hocalarından, Henri Labrouste (1801$1875)^{21}$ ile birlikte tasarlamışlardır. 1851 yılında Viollet-le-Duc, St-Denis Kilisesi restorasyonuna, 1852 yılında da ölümüne kadar sürecek olan Carcassonne'daki çalışmalarına başlamıştır (Pevsner, 1972, s. 198).

Viollet-le-Duc, 1853 'de, daha önce bahsettiğimiz devletin yapım faaliyetlerini kontrolü altında tutan kurumlardan bir diğeri olan, Conseil des Edifices Diocésains başkanı olmuştur. 1856'da Ulusal Sanat ve Endüstri Sergisi'nde birincilik madalyası kazanmıştır. Bu süre içerisinde çeşitli restorasyon projelerini sürdürmekte olan Viollet-le-Duc, Rhine'de M. Dolifus için bir kent evi (1853) ve M. Polonceau için Sebastopol Bulvarı'ndaki 23 numaralı evi (1856) tasarlamıştır (Middleton, 1967, s. 800; Packard, 1989, s. 254).

Viollet-le-Duc'ün Ortaçağ dönemi mimarlığı üzerine yaptı̆̆ 1 araştırmalarının ve Gotik mimarlık üslubu üzerine düşüncelerinin, önce Fransa'da daha sonra dünyada yayılmasını sağlayan, ünlü Dictionnaire Raisonné de l'Architecture Française du XI au XVI Siècle isimli ilk büyük eseri; 1854 yılında 40 yaşında iken yayınlanmaya başlamış, 10 ciltlik bu eseri 7 yıl içinde tamamlamıştır (Summerson, 1963, s. 140).

Viollet-le-Duc, kızı Marie-Sophie'yi öğrencisi Maurice Ouradou (1822-1884) ile evlendirdiği yıl olan, 1857 'de babasını kaybetmiştir. İmparator III. Napoléon ve ailesine yakınlaştığı belirtilen bu dönemde, imparatora özel bir konut olarak Gotik üslupta düzenleyeceği Pierrefonds Şatosu'nun restorasyon projesinde görevlendirilmiştir (Resim 13-14) (Middleton, 1967, s. 800; Packard, 1989, s. 254).

Viollet-le-Duc'ün düşüncelerini benimsediği ve çok saygı duyduğu Henri Labrouste'un, 1856'da Ecoles des Beaux-Arts'daki atölyesini kapamasiyla, öğrencileri Anatole de Baudot'nun önderliğinde Viollet-le-Duc'den atölye açmasını talep etmişler ve Viollet-le-Duc de 15 Ocak 1857 'de Ecoles des Beaux-Arts'da bir atölye kurmuştur. Birkaç ay sonra kapanan bu atölyede Viollet-le-Duc atölye dışından isteyenlerin de katılabileceği bir ders açmış ve bu derslerin özetlerini Encyclopédie d'Architecture' de yedi bölüm halinde yayınlamıştır. Her ders yapıldıktan sonra birer

\footnotetext{
${ }^{20}$ Parker İngiltere'de Gotik mimarlık üslubuna yönelik araştırmalar yapmış, kitaplar yazmış bir arkeologdur. Viollet-leDuc'ün Parker'ın 1845'de yayınlanmış olan A Glossary of Terms Used in Grecian, Roman, Italian and Gothic Arcitecture isimli eserini çok beğenmiş olduğu belirtilmektedir (Bressani, 2000a, s. 136).

${ }^{21}$ Henri Labrouste, yapımına 1843'de başlanıp 1851'de tamamlanan neo-Rönesans üslupta tasarladığı Sainte-Geneviève kütüphanesini, dökme demir yapım sistemiyle inşa ederek, tam da bu yıllarda Paris mimarlık ortamında çığır açmış bir mimardır.
} 
kitap çıkmıştır (Pevsner, 1972, s. 207) ${ }^{22}$.Viollet-le-Duc, bu derslerde anlattığı mimarlık üzerine düşüncelerini yazarak başladığı, önce Fransa daha sonra dünya mimarlık ortamında çı̆̆ır açacak olan Entretiens sur l'Architecture (Mimarlık Üzerine Konuşmalar) isimli ünlü eserinin hazırlıklarına başlamış; iki ciltlik eserin ilk cildi 1863 'de; ikinci cildi ise 1870-1871 Fransa-Prusya savaş1 sonrasında, 1872'de yayınlanmıştır (Summerson, 1963, s. 140).

1858 yılında kendisine Milano Güzel Sanatlar Akademisi üyeliği ve "Officier de la Légion d'Honneur" ödülü verilen Viollet-le-Duc, 1860 yılında Tarihi Anıtlar Komisyonu, Bilimsel Tarih ve Arkeoloji Derneği, Milano Güzel Sanatlar Kraliyet Akademisi, Floransa Güzel Sanatlar Akademisi ve Amerika Mimarlar Enstitüsü üyesi olmuştur.

1861 'de dönemin mimarlık dergilerinden biri olan Encyclopédie d'Architecture'de ilginç bir haber yayınlanır. Derginin editörü olan Bance'nin kütüphanesinden Viollet-le-Duc'ün portre fotoğrafı satın alınabilecektir. Bu haber Viollet-le-Duc'ün bu dönemde ne kadar ünlü ve popüler bir mimar olduğunu açıkca göstermektedir (Encyclopédie d'Architecture, 1861, s. 64).

1861 y1lında Reims Katedrali restorasyonuna başlayan Viollet-le-Duc, 1862'de, ölümüne kadar yoğun mimari çalışmalarını sürdüreceği Condorcet sokağı 68 numaralı yapıyı kişisel ofisi olarak tasarlamıştır (Resim 2). Aynı yıl Korsika'ya kısa bir gezi yapmış, Prusya Kızıl Kartal Örgütü tarafından kendisine şövalyelik ünvanı verilmiştir.

İmparatorluğun 13 Kasım 1863'de Güzel Sanatlar Okulu'nda yürürlüğe koyduğu yeni düzenlemede III. Napoleon'un atamasıyla, Viollet-le-Duc okulun "Sanat ve Estetik Tarihi" hocas1 olmuştur (Encyclopédie d'Architecture, 1863, s. 222). Viollet-le-Duc Ecole des Beaux-Arts' da, kabul gören mimarlık eğitim metotlarını tehtid eden görüşleri nedeniyle verdiği ilk dersten itibaren, akademinin hem hocaları hem de öğrencileri tarafindan, özellikle ressam Jean Auguste Dominique Ingres ve öğrencileri tarafindan tepkiyle karşılanmıştır. Bu nedenle, 18 Mart 1864'de okuldaki son dersini verdikten sonra akademiden ayrılan Viollet-le-Duc, aynı gün okulun Başkanı M. Coumont’a yazdığı mektupta, daha sonra ise yazdığ 1 birçok yazıda, okulun eğitim anlayışının yenilenmesi gerektiğine ilişkin düşüncelerini belirtmiş, bu yöndeki çabasını hayatı boyunca sürdürmüştür (Viollet-le-Duc, 1902, s. 48-50). ${ }^{23}{ }^{1865}$ 'de ise Prosper Mérimée ile birlikte Ecole Centrale d'Architecture (Mimarlık Merkezi Okulu) adında yeni bir okul kurmuşlardır. Bu okul 1930'a kadar eğitim vermiştir (Van Zanten, 1994, s. 63). ${ }^{24}$

\footnotetext{
${ }^{22}$ Viollet-le-Duc 1. derste mimarlığın heykel ve resim sanatıyla ilgisi, bu sanatların genel gelişim tarihini, 2. derste batı uygarlı̆̆ının mimarlık tarihini, 3. derste antik dönemden 19. yüzyıla kadar inşaat tekniklerini, 4. derste Ortaçă̆'dan Rönesans'a kadar Roma'da ve Fransa'da mimarlık, 5. derste kamu ve özel inşaatların yönetimi, 6. derste yapıların korunması ve 7. derste bayramlar ve kamuya açık törenlerde yapıların iç dekorasyonu konularını anlatmıştır. Ayrıntılı bilgi için bkz. (Encyclopédie d'Architecture, 1857, s. 1-3)

${ }^{23}$ Jean-Jacques Aillagon, Viollet-le-Duc'ün 1963 'de Entrentiens kitabının yayınlanmasına kadar École Des Beaux-Arts'da reform yapılması yolunda çeşitli makaleler yazdığını ve ölümüne kadar da bu düşünceyi geliştirdiğini belirtmektedir (Foucart vd., 1980, s. 396).

${ }^{24}$ Mimarlık dergisindeki bir yazıda 2 Mayıs 1865'de kurulmuş olan Société de l'Ecole Centrale d'Architecture üyeleri listesi verilmekte ve bahsedilen okulunun eğitim ve öğretim programına yönelik kurul kararları sunulmaktadır. Bu kurulun başkanlığını Viollet-le-Duc'ün ve MM. Emile de Girardin'in yaptığı belirtilmektedir. Kurul, okulun mimarlık ders programında mimarlık tarihi ve konstrüksiyon derslerinin ağarlığı olması gerektiği yönünde karar almıştır. Okulun hocaları ise E.E. Viollet-le-Duc, Anatole de Baudot, Ferdinand de Lesseps, Eugène Flachat, Dupont de l'Eure, JeanBaptiste André Godin ve Émile Muller'dir. (Encyclopédie d'Architecture, 1865, s. 23-26).
} 

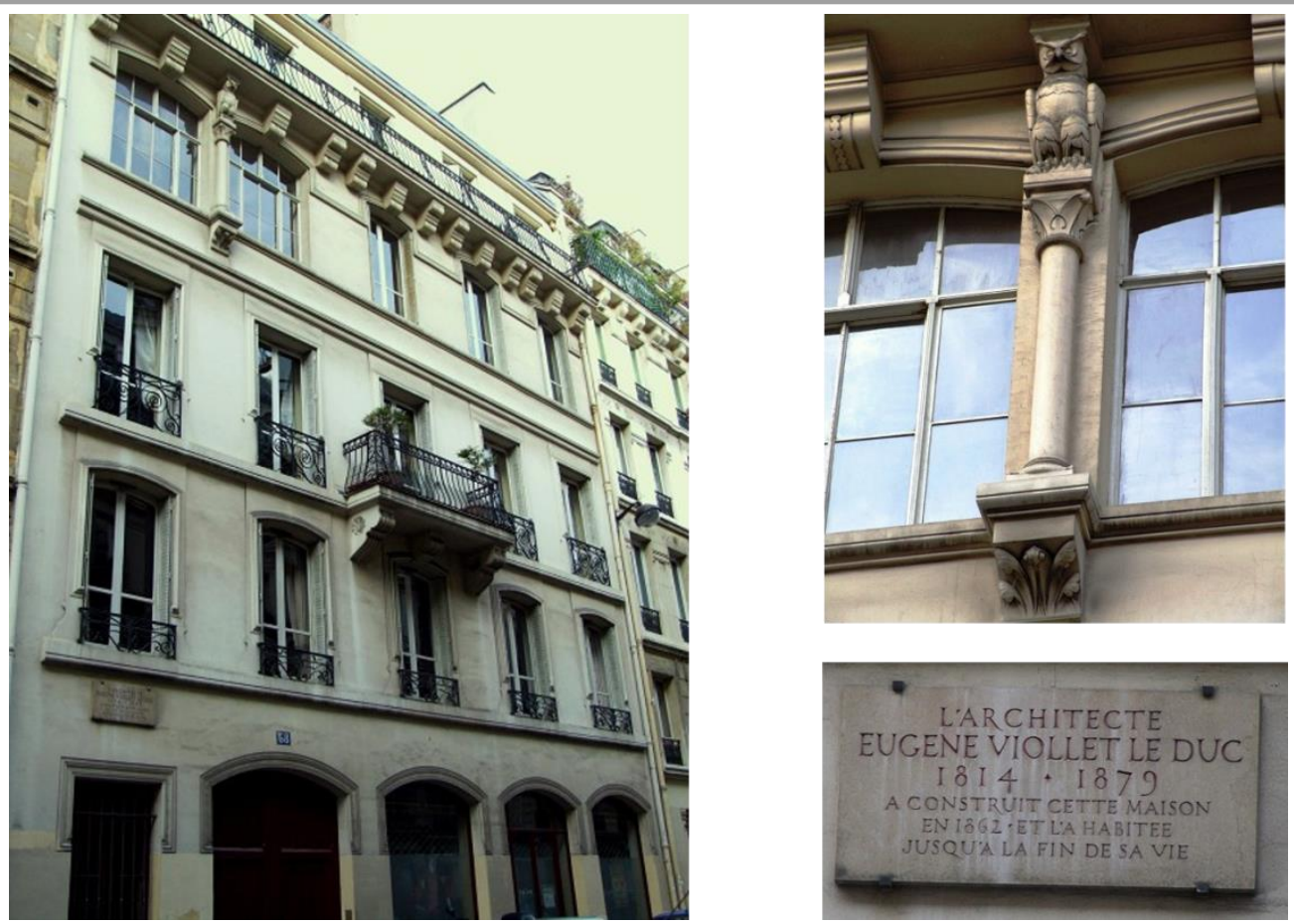

Resim 2: Condorcet Evi, cepheden detay ve bilgilendirme levhası (Tosun, 2008, s. 169-170, r.3234) "Mimar Eugene Viollet-le-Duc, 1814-1879, bu yapıyı 1862'de inşa etti ve hayatının sonuna kadar bu evde yaşadı."

Viollet-le-Duc'e 1863 yılında Amsterdam Mimarlık Derneği, Lizbon Güzel Sanatlar Kraliyet Akademisi, Belçika Güzel Sanatlar, Edebiyat ve Bilim Kraliyet Akademisi üyelikleri verilmiştir. 1864'de Britanya Mimarları Kraliyet Enstitüsü'nden altın madalya kazanmış, İspanya St. Ferdinand Kraliyet Akademisi tarafindan İspanya'daki mimarlık etkinliklerini değerlendiren ve ödüllendiren jurinin seçkin üyesi olarak görevlendirilmiştir. 1865'de de Viyana Akademisi üyesi olmuştur. Yaşlı ve yorgun olduğu için kendisine önerilen taşradaki mimari restorasyon işlerini artık yapamayacağını belirten Viollet-le-Duc, 1868'de yaptı̆̆ iki gezi ile Mont Blanc'daki çalışmalarına başlamıştır. 1869'da kendisine İmparatorluk Güzel Sanatlar ödülü verilmiştir.

1870-71 yılları arasında Fransa-Prusya savaşında İstihkam Sınıfı İkinci Kumandanı olarak görev almış, yönetimindeki 1200 askerle Noissy Kalesini işgal etmiş, Paris çevresindeki kaleleri sağlamlaştırmış, Notre-Dame ve St-Denis bölgelerini korumuştur.

1872'de Lozan Katedrali restorasyonu için görevlendilen Viollet-le-Duc, Londra'da düzenlenen Dünya Fuarı'nın Komisyon başkanlığını da üstlenmiştir. 1873 yılında Viyana'da düzenlenen Dünya Fuarı'nda madalya kazanmış; aynı yıl Académie des Beaux-Arts tarafından kendisine teklif edilen akademi üyeliğini reddetmiş, ertesi y1l da politik nedenlerle Conseil des Edifices Diocésains başkanlığı görevinden istifa etmiştir.

Brezilya Kralı tarafindan da şovalye ilan edilen Viollet-le-Duc, 1874 yılında Cenevre Sanat Derneği üyesi olmuştur. Viollet-le-Duc, 1875 yılında Philadelphia'daki Amerikan Felsefe Derneği'ne, 1876 yılında Boston'daki Amerikan Sanat ve Bilim Akademisi'ne ve Paris Mimarlar Odası Konseyi'ne üye olmuştur. Aynı yıl Entretiens kitabını ingilizceye çevirmiş olan Benjamin Buncknall ile birlikte Mont Blanc'a 20 günlük bir seyahat yapmıştır. 1872'de Chamonix'de kendisine yazlık bir ev inşa ettiren Viollet-le-Duc iki yıl sonra Lozan'da kendisi için La Vedette evini inşa etmiştir (Resim 3). 
Babası gibi çok zengin bir kütüphaneye ${ }^{25}$ sahip olduğu bilinen Viollet-le-Duc'ün, her gün; sabah saat 7 ile 9 arasında yazılarını yazdığı, 9 ile 10 arasında ziyaretlerini yaptığı, sabah 10 ile akşamüstü 5 arasını mimari çalışmalarına ayırdığ 1 , akşam 8'e kadar yemeğini yiyerek çeşitli ziyaretlerde bulunduğu, akşam 8'den sonra gece yarısı 12 'ye kadar okuma ve araştırmalar yaptığ 1 ve bu yoğun programına hayatı boyunca sadık kaldığı belirtilmektedir (Pevsner, 1969, s.15).
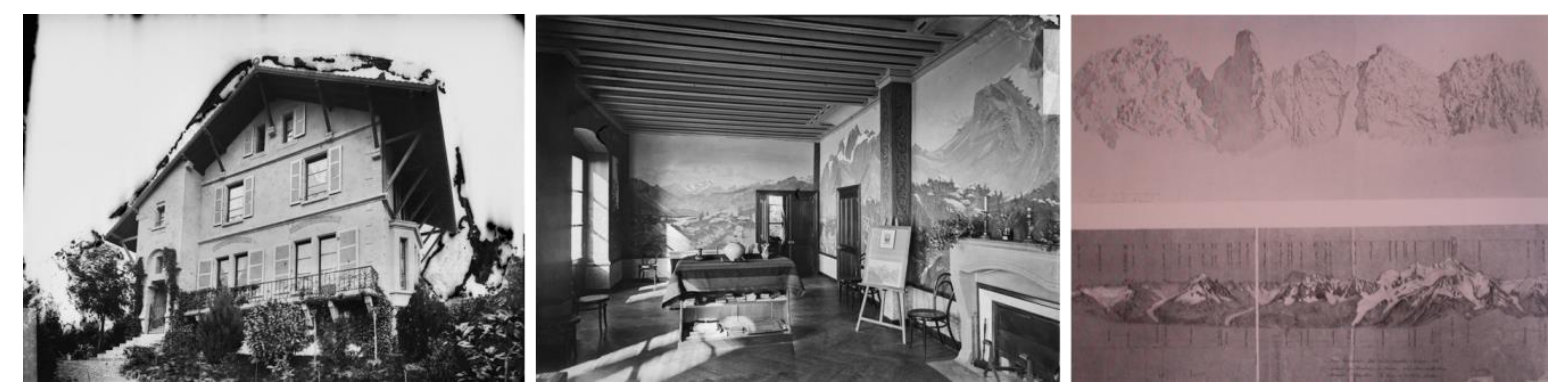

Resim 3: Viollet-le-Duc'ün Lozan'daki La Vedette Evi (1874-1876), giriş cephesi (photo.rmn.fr, 2021), iç mekan (are.na, 2021), Monc Blanc Çalışması (1868-1875) (Foucart vd., 1980, s. 364)

Bu yoğun çalışma temposu nedeniyle rahatsızlanan Viollet-le-Duc, 1876'nın Ocak ayında bir süre dinlenmeye çekilmiştir. Ancak, Ağustos 1878 'de rahatsızlığı artınca dinlenmek üzere Lozan'daki evi La Vedette'ye yerleşen Viollet-le-Duc, gezmeyi ve özellikle Mont Blanc'a yürüyüşler yapmayı çok sevmesine rağmen artık sadece kısa yürüyüşler yapabilmektedir (Resim 3). Sağlığının kötüye gitmesine rağmen Lozan Katedrali restorasyonu çalışmalarını da sürdürmüş; eylül ayında, restorasyonları halen devam etmekte olan Carcassonne ve Pierrefonds'u ziyaret etmiştir. 1879 yılında, duvar resimlerinin kopyalarının da sergilenebileceği bir Heykel Müzesi tasarımı üzerinde çalışmakta olduğu belirtilmektedir. Aynı yıl, öğrencisi ve arkadaşı olan Emile Millet için bir anıt mezar tasarlamıştır. 10 Ağustos'da ise Lozan'a dönmüş, Mont Blanc dağına 2 hafta süren bir gezi yaptıktan iki hafta sonra, henüz 65 yaşında iken, 15 Eylül 1879 tarihinde kendi evinde vefat etmiştir. Lozan La Salle Mezarlığı'nda yapılan küçük bir törenin ardından kendi isteği üzerine Lozan'daki Bois-de-Vaud Mezarlığına gömülmüş, vasiyeti üzerine organları 1877'de asli üyesi olduğu Paris Antropoloji Derneği'ne bağışlanmıştır.

\section{Mesleki Etkinlikleri}

Viollet-le-Duc aile çevresinden tanıdığı sanatçı, yazar ve bürokratlarla yakın ilişkiler içinde bulunarak devletin yapı faaliyetlerinden sorumlu kurumlarında önemli görevler almış, başarıları sayesinde kısa sürede bu kurumlarda üst düzey yetkilere sahip olmuş, Fransa'daki mimarlık ve mimari restorasyon faaliyetlerini yönetimi altında tutan devletin önemli kurumlarında merkezi ve etkin roller üstlenmiştir. Bu yetkiler ona, kendini mesleki anlamda geliştirebileceği yoğun mimari uygulamalar yapma firsatını vermiş; hayatının sonuna kadar mimarlığa araştırmacı ve eleştirel yaklaşımıyla mesleki anlamda kendini geliştirmiştir.

Fransız ihtilalinde yıkılan anıtların onarılması zorunluluğu ve ortaçağ yapılarının restorasyonu için kurulan Fransız Tarihi Anıtlar Komisyonu'nda Prosper Mérimée ile çalışan Violletle-Duc, Fransa'da restorasyon işlerinin öncüsü olmuş; birçok ortaçağ yapısı onun önderliğinde belgelenmiş ve restore edilmiştir (Pevsner, 1972, s. 194). Fransa'da iki kentin surlarının, 26

\footnotetext{
${ }^{25}$ Kütüphanesinde 2000'i aşkın kitap bulunduğu belirtilen Viollet-le-Duc'ün ölümünden sonra 1880'de bu kitapların açık arttırma ile satıldığı bilinmektedir. Kitapların 166 tanesinin din kitabı, 180 tanesinin fen bilimleri kitabı, 850 tanesinin sanat kitab1 olduğu belirtilmektedir (Eigen, 1999, s. 226; Pevsner, 1972, s. 215). Middleton 1992'de yayınlanan Laurent Baridon'un l'Imaginaire Scientifique de Viollet-le-Duc (Viollet-le-Duc'ün Bilimsel Hayalgücü) isimli kitabını tanıttığ yazısında, bu kitapların listesinin de bulunduğunu söylemektedir (Middleton, 1998, s. 764).
} 
katedralin, 21 şatonun, 6 manastır yapısının, 71 kilisenin, 6 köprünün, üç belediye sarayının, iki okulun, bir tiyatro yapısının, bir kulenin, bir çeşmenin, bir büstün ve Papalık Sarayı'nın rölövelerini yapmıştır. Bunun yanı sıra Avrupa'da da bir çok yapının rölöve çizimlerini yapmıştır. Almanya'da üç kentin surlarının, altı katedralin, iki kilisenin, bir sinagogun, bir şatonun, iki köprünün, bir kulenin, bir müzenin, bir anıtın rölövelerini; İngiltere'de beş katedralin, iki manastırın, iki konutun ve iki kulenin rölövesini; İsveç’te üç katedralin, iki kilisenin, bir köprünün, Belçika'da bir şapelin, İtalya'da bir konutun, Çekoslavakya'da bir katedralin, Avusturya'da dağ evlerinin rölövelerini çizmiştir. Fransa'da iki şehrin surlarının, bir şehrin kalesinin, dokuz katedralin, 29 kilisenin, üç manastır yapısının, 12 şatonun, iki kulenin, üç köprünün, bir okulun ve Papalık Sarayının restorasyonunu yapmıştır. Bunun yanı sıra, İsveç’te bir katedralin ve bir şapelin restorasyonunu yapmış; Polonya' da bir katedralin, Hollanda'da bir kilisenin, Belçika'da Belediye Sarayı'nın restorasyon projesini çizmiştir. ${ }^{26}$

Viollet-le-Duc'ün Fransa'da, dokuz kilise tasarımından beşi, yedi şapel tasarımından altısı inşa edilmiş; bir katedralin cephesini de tasarlamıştır. Dört yönetim binası, üç okul, bir gaz fabrikası, bir belediye sarayı tasarımı yapmış ve bir müzenin de içini düzenlemiştir. Paris'de inşa edilen 11 apartman tasarımı dışında yedi konut tasarlamış, bunlardan sadece biri inşa edilmiştir. Ayrıca diğer tasarımları arasında dokuz anıt mezar, 11 anıt, üç bahçıvan evi, üç bekçi evi, iki çeşme, bir hangar, bir sokak tuvaleti, bir çamaşırhane yapısı bulunmaktadır. Katıldığı iki yarışma projesinden biri olan Paris Opera binası tasarımı yarışmayı kazanamadığı için inşa edilmemiştir. Viollet-le-Duc ayrıca İsveç'de bir şato, bir şapel, bir anıt ve kendisi için bir ev inşa etmiştir. İspanya'da ve Rusya'da inşa edilen birer anıt projesi bulunmaktadır. New York'daki Özgürlük Anıtı'nın strüktürel tasarımını da Viollet-le-Duc yapmıştır. ${ }^{27}$
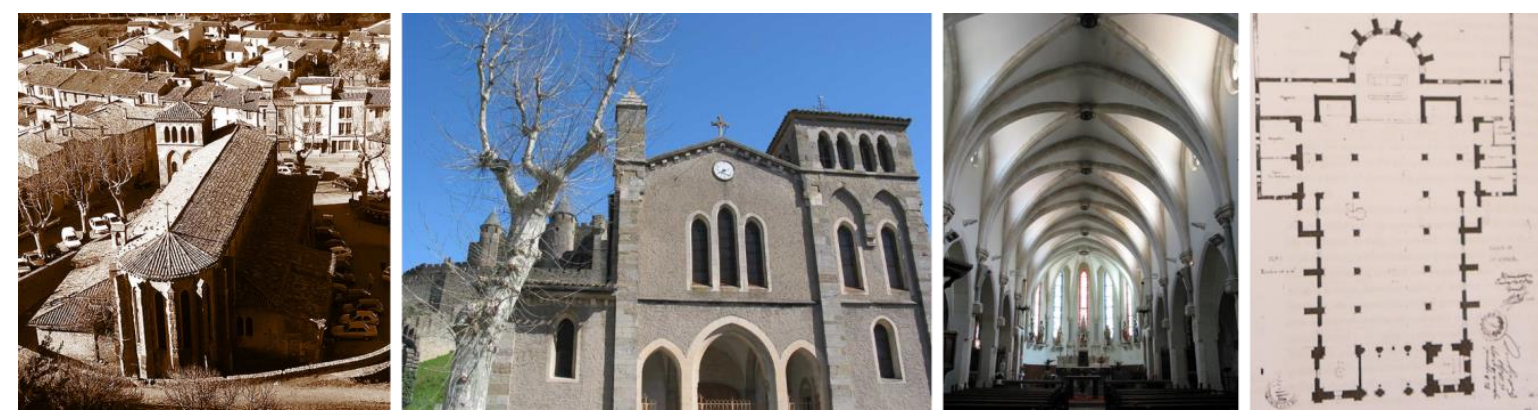

Resim 4: Viollet-le-Duc'ün Carcossone'daki Saint Gimer Kilisesi, genel görünüm, cephe, iç mekan (Tosun, 2008, s. 163-164, r. 21-23) ve plan (Macclintock, 1981, s. 224)

İşlevsel ihtiyacı karşılayan basit bir kilise tasarımı yapması istenen Viollet-le-Duc'ün Carcossone'da Saint Gimer (1852-59) Kilisesi onun mimari tasarıma yaklaşımını anlamamız için güzel bir örnektir. Kilisesi'nin az bütçeli olması nedeniyle Viollet-le-Duc bu projede ekonomik ve çevrenin karakterini yansıtan bir tasarım anlayışı benimsemiştir. Kesme taş kaplamalı yığma yapının üstünü civar konutlarında görülen kırmızı kiremitli ahşap bir çatıyla örtmüştür. Önce kilise için bir yer belirlemesi gereken Viollet-le-Duc, kilise kulesini üç caddenin kesiştiği yere yerleştirmiş ve yapıyı Saint Gimer'nin doğduğu şehir yönüne bakacak şekilde konumlandırmıştır. Viollet-le-Duc Partheon'da belirlediği Mısır üçgeni oranlarını uygulayarak yaptığı basit bir geometriye sahip olan orta nef, iki yan sahın ve bir kuleden oluşan haç planlı bir kilise tasarlamıştır. Yapının maliyetinin

\footnotetext{
${ }^{26}$ Viollet-le-Duc'ün belgelediği ve restore ettiği yapıların listesi için bkz. (Tosun, 2008, s. 203-214)

27 Viollet-le-Duc'ün tasarımlarının listesi için bkz. (Tosun, 2008, s. 210-212). Fransız heykeltraş Frederic-Auguste Bartholdi (1834-1904) tarafından tasarlanmış olan Özgürlük Anıtı'nın (1879) çelik konstrüksiyon tasarımını AlexandreGustave Eiffel (1832-1923) ile birlikte Viollet-le-Duc yapmıştır.
} 
ekonomik olması için binayı alçak tutmuş ve kulesini de çok yüksek yapmayarak basit bir strüktürle tek katlı mütevazı bir yapı inşa etmiştir (Resim 4).

Plan şeması için Carcassonne'daki Saint Etienne ve Saint Vincent kiliselerinin plan özelliklerinden ve yerel mimarinin özelliklerinden esinlenen Viollet-le-Duc, yapısını 12., 13. ve 14. yüzyıl kilise mimarlığının özelliklerini taşıyan bir eser haline getirmiştir. Viollet-le-Duc'ün Saint Gimer'nin tasarımı için, plan şemasında ve yapı malzemesinde yerel kiliselerden esinlenmiş olması; mantıklı bir işlevsel analizle tarihsel mimari biçimleri ihtiyaca yönelik ekonomik ve sade bir mimari biçimlenmeye uygun uyarlanması, onun mimari tasarıma yaklaşımını ortaya koymaktadır (Macclintock, 1981, s. 218-235).
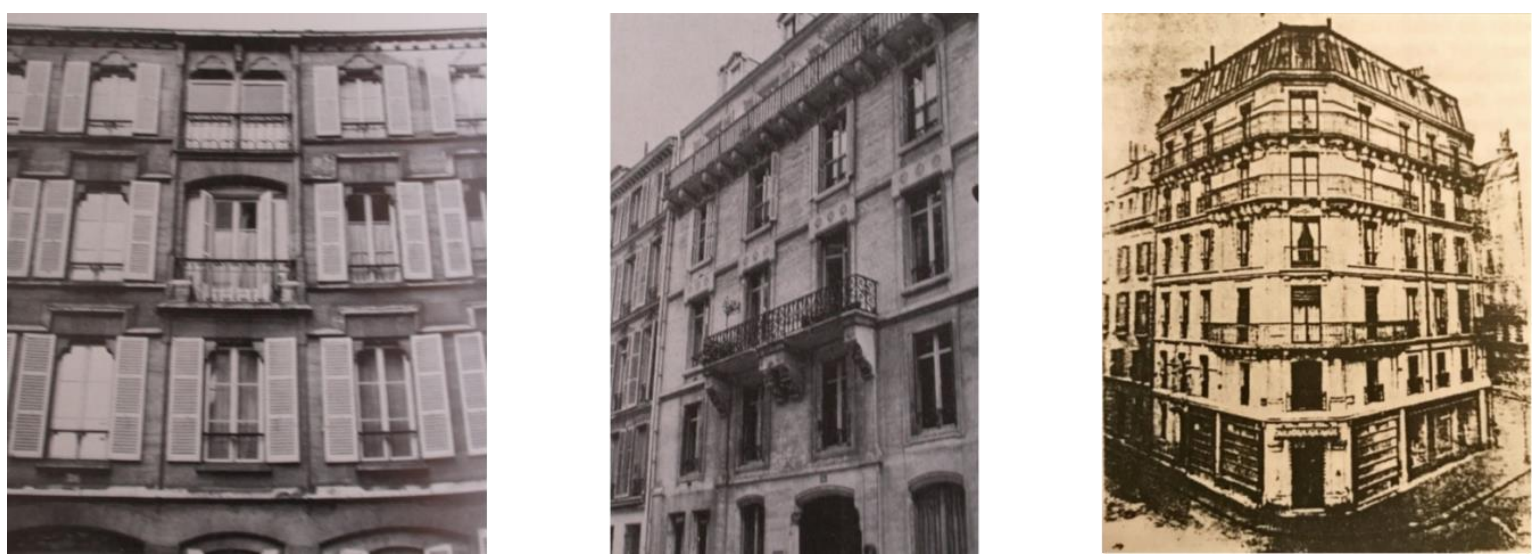

Resim 5: Viollet-le-Duc’ün konut tasarımları, sırasıyla Courmont Evi, Milon Evi, M. Sauvage Evi

(Foucart vd., 1980, s. 242-243)

Viollet-le-Duc, Paris'de Rue de Berlin'de ${ }^{28}$, Mérimée'nin yakın bir arkadaşı olan Henri de Courmont için 22 nolu Courmont Evi (1846)'ni tasarlamıştır. Paris sokaklarında bulunan konutların genel mimari özelliklerini taşıyan bu yapının cephesinde özellikle balkon altındaki saçaklarda görüldüğ̈̈ gibi yapının strüktürel ve işlevsel elemanlarında Gotik detaylar uygulamıştır. Daha geç dönemde Paris'de tasarladığı Rue de Douai' de 15 nolu Milon Evi (1857-1860), Rue de Chauchat'da 23 nolu M. Sauvage Evi ve Rue Condorcet'de 68 nolu kendi evi (1862-3) gibi kentsel konut yapılarında ise (Resim 2, 5) Viollet-le-Duc'ün Gotik mimarlığ bulmadığı için uygulamadığı belirtilir (Middleton, 2003, s. 356-357). Öte yandan St. Gimer kilisesi tasarımındaki benzer bir yaklaşımı benimsemiş olabileceğini düşünmek kanımızca yanlış olmayacaktır.

Viollet-le-Duc'ün konut tasarımları arasında en önemlilerinden biri de Lozan'da kendisi için tasarladığ 1 (1874) ve son yıllarını geçirdiği La Vedette evidir. ${ }^{29}$ Cenevre gölüne bakan bu evin ilkel konut ile modern konutun bir sentezi olduğu söylenmektedir. Ancak yapı günümüze gelememiş, 1975 yılında yıkılmıştır (Elliot, 1986, s. 9). Viollet-le-Duc, Lozan'daki çalışmaları sırasında La Vedette evinin duvarlarına Mont Blanc ${ }^{30}$ peysajları yapmıştır. Viollet-le-Duc'ün Mont Blanc dağı üzerine 1868 yılında başlayıp ölümüne kadar zevkle sürdürdüğü jeolojik bir çalışması da bulunmaktadır. Dağın yüzlerce çizimini yapmış ve topografik bir haritasını hazırlamıştır (Resim 3).

Viollet-le-Duc, dönemin mimarlık kompozisyon anlayışında zorunlu bir uygulama olan simetriye karşı olan tutumunu, konut yapılarında doğadan kaynaklanan bir özellik olduğunu

\footnotetext{
${ }^{28}$ Bugün yapının bulunduğu sokağın ismi Rue de Liège'dir ve yapı numarası 28'dir.

${ }^{29}$ Viollet-le-Duc'ün Fransa ve İsviçre'de yapmış olduğu kent evleri için bkz. (Melissa, 2003).

${ }^{30}$ Fransızcada Beyaz Dağ olarak bilinen Mont Blanc, Alp Dağları'nın en yüksek olanıdır. Viollet-le-Duc, dağdaki çalışmaları sırasında kullanmak üzere en yakın iki kasabadan biri olan Chamonix'de kendisine bir ev inşa etmiştir.
} 
savunduğu asitmetrik kompozisyonlar tasarlayarak göstermiştir (Pevsner, 1972, s. 211). Hitchcock, Viollet-le-Duc'ün kamu yapılarını, İkinci İmparatorluk döneminin mimari üslubunu benimseyerek, eklektik bir üslupta tasarladığını; 1850'nin sonlarında tasarlamış olduğu yapıların ise Milon evi'nde olduğu gibi İngiliz Yüksek Viktoryen Gotiği özellikleri taşıdığını belirtmektedir (Hitchcock, 1982, s. 280).

Viollet-le-Duc'ün Ortaçağ dönemi araştırmalarında kazandığı uzmanlaşma onu dönemin herşeyini anlatmaya; kıyafetlerine, silahlarına, aksesuarlarına ilişkin öneri tasarımlar yapmaya götürmüştür. ${ }^{31}$ Histoire d'une Maison (Bir Evin Tarihi) isimli kitabında duvar kağıdı tasarımları bile bulunmaktadır. Bunun dışında imparator için lüks bir tren ve vagonlarının da mobilyalarını tasarlamıştır. ${ }^{32}$ Tasarımlarındaki, örneğin tren vagonu tasarımında ahşap oyma tekniğiyle yaptığ 1 sarmaşık ve haşhaş çiçeklerinden oluşan bitkisel süslemeler Art Nouveau habercisi olarak nitelendirilmektedir (Resim 6).
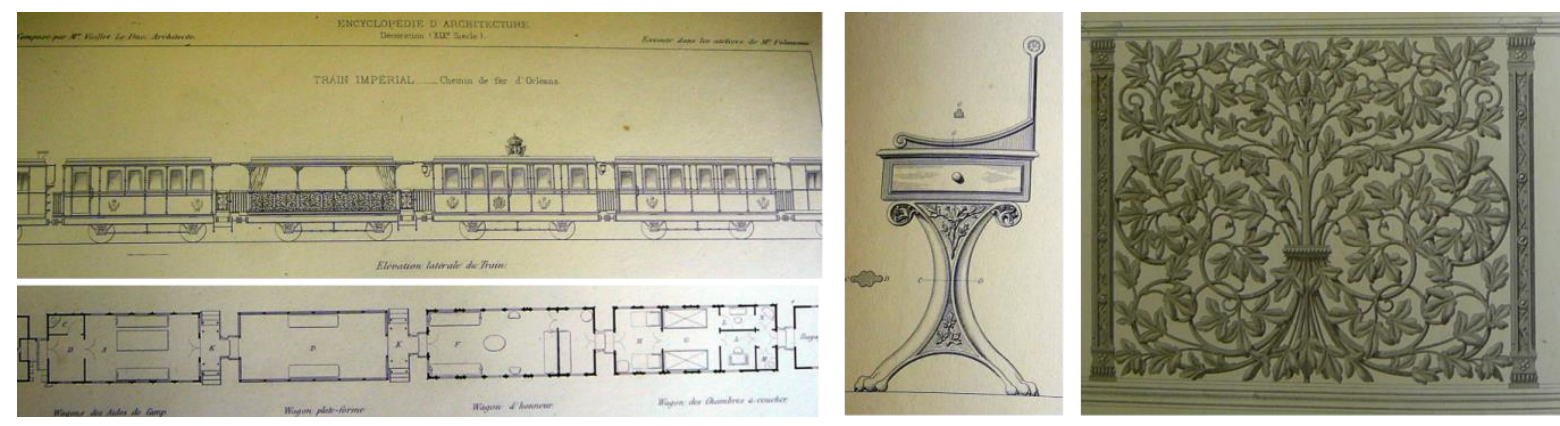

Resim 6: Viollet-le-Duc'ün İmparatorluk treni tasarımı (1857), vagon için tasarladığı mobilya ve süsleme detayı, (Encyclopédie d'Architecture, 1859, s. 129-131)

Ayrıca Viollet-le-Duc'ün, İmparatorluğun önemli kutlama günleri için dekor tasarımları, tiyatro oyunları için kostüm tasarımları, bir çok desen çalışması ve 1870-71 yılları arasında katılmış olduğu Fransa-Prusya savaşı sırasında yapmış olduğu suluboya resimleri de bulunmaktadır (Resim 7).

Summerson, Viollet-le-Duc'ün mimari yapı etkinliklerinin muazzam aydınlatıcı belgeler olduğunu, ancak Viollet-le-Duc'ün mimari çalışmaları içinde ortaya koyduğu mimarlık düşüncelerinin yanında çok önemsiz kaldığını belirterek Viollet-le-Duc'ün mimarlık düşüncelerini anlamamızda yayınlarının önemini ortaya koymaktadır (1963, s. 156).

Viollet-le-Duc'ün Ortaçağ mimari mirasına ilişkin biri mimarlı̆̆ını anlatan on ciltlik, diğeri mobilyalarını anlattığı altı ciltlik iki ansiklopedik kitabı, iki mimarlık kuram kitabı; iki ciltlik mimarlık üzerine düşüncelerini anlattı̆̆ kuramsal kitabı ve bu kuramlarının bir uygulaması olan Rus sanatı üzerine yazdığı bir kitabı vardır. Bunların yanı sıra beş hikaye kitabı, restorasyonunu yapmış olduğu yapılara ilişkin altı monografi kitabı, mimarlık eğitimine ilişkin üç kitabı, Mont Blanc'da yaptığ 1 jeolojik çalışmaya ilişkin bir kitabı, askeri mimarlığa ilişkin üç kitabı bulunmaktadır. Ayrıca, başka araştırmacılarla ortak çalışmalarına ilişkin birlikte yazdıkları altı kitap ve önsözünü yazdığı dört kitap bulunmaktadır. Viollet-le-Duc yukarıda saydığımız 22 kitabı, altı ortak yayını ve dört önsözünün yanı sıra dönemin önemli mimarlık dergilerinde 200'ü aşkın makale, eleştiri ve gezi yazıları yazmıştır. Yazdığı mektuplar derlenerek dört kitap, mimari süsleme üzerine yazdığ1 makaleler derlenerek bir kitap yayınlanmıştır. ${ }^{33}$

\footnotetext{
${ }^{31}$ Ayrıntılı bilgi için bkz. 1980'de düzenlenen Sergi Kataloğu (Foucart vd., 1980).

32 Viollet-le-Duc'ün imparator için tasarladığı tren vagonu tasvir ve çizimleri için bkz. (Encyclopédie d'Architecture, 1859, s. 129-131)

${ }^{33}$ Viollet-le-Duc'ün yayınlarının listesi için bkz. (Tosun, 2008, s.215-228)
} 

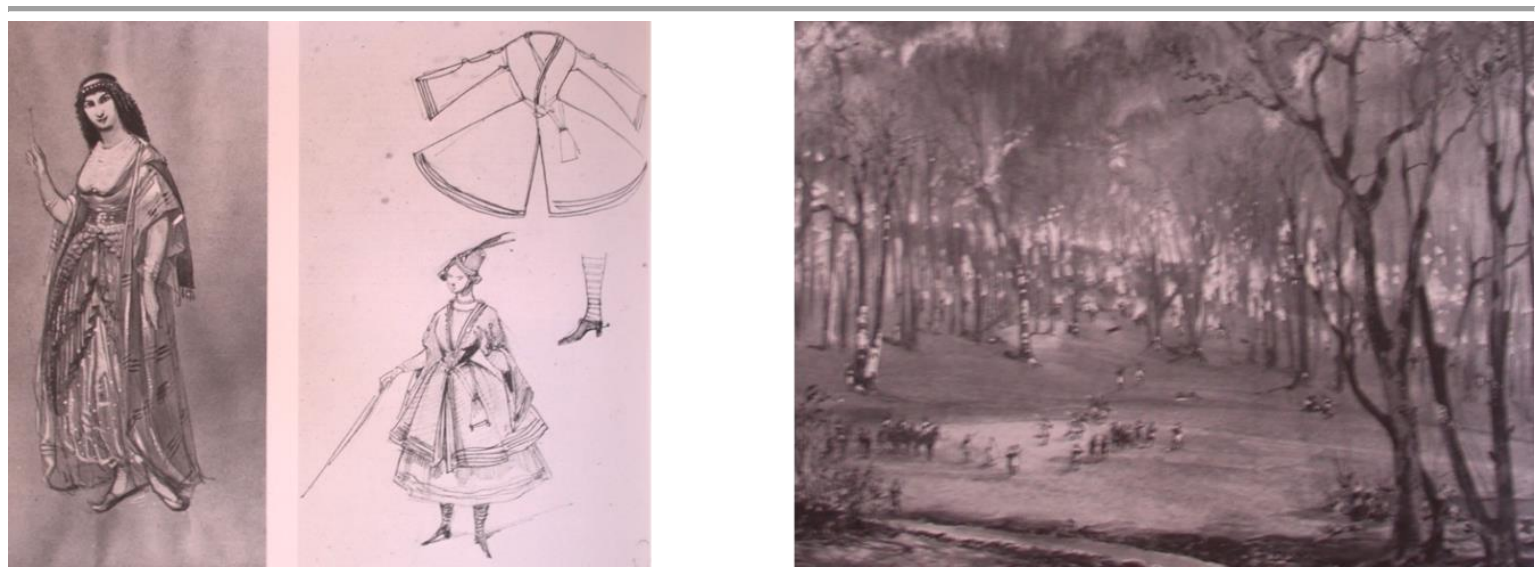

Resim 7: Viollet-le-Duc'ün tiyatro için kostüm tasarımlarından ve suluboya resim çalışmalarından örnekler (Foucart vd., 1980, s. 346, 359)

Viollet-le-Duc bu yayınları ile sadece Fransa'da değil, birçoğunun 1864'den itibaren İngilizce'ye çevrilmesiyle dünyada da tanınmış ve 19. yüzyılın ikinci yarısından itibaren dünya mimarlık ortamında, yarattığı çeşitli tartışma platformlarıyla, en ünlü mimarlardan biri olmuştur. Bazı yayınları da tekrar basılan Viollet-le-Duc'ün hem mimarlık etkinlikleri hem de mimarlık üzerine düşünceleri yaşadığı dönemden itibaren pek çok araştırma ve eleştiri yazısına da konu olmuştur. ${ }^{34}$

20. yüzy1l İngiliz mimarlık tarihçilerinin öncüsü kabul edilen Sir John Newenham Summerson (1904-1992) Avrupa mimarlık tarihinde Viollet-le-Duc'ün, Leon Battisti Alberti'den (1406-1472) sonra yaşamış en önemli ve en ünlü mimarlık kuramcısı olduğunu belirtmekte, modern mimarlığın kuramlarının da mimarlık dünyasının son büyük kuramcısı olan Viollet-le-Duc'ün mimarlık düşünceleri üzerine temellendiğini vurgulamaktadır (1963, s. 135).

\section{Mimari Miras ve Korumacılık Alanındaki Öncü Rolü}

Viollet-le-Duc'ün çalışmaları 'mimari mirası' anlamaya, belgelemeye, gelecek nesillere aktarmaya temellenmektedir. 'Mimari mirasın' mimarlık eğitimindeki önemini ortaya koymaya çalışmış; 'mimari mirasın' hem çağdaş (aynı zamanda modern olan) hem de ulusal bir mimari için kaynak olarak kullanılması yönündeki mimari anlayışına yönelik bilimsel bir yöntem geliştirmiş; bu yöntemi restorasyonlarında da kullanmıştır.

Tüm bunların başlangıcında onu en çok etkilemiş olan düşünürlerden biri 1830 kuşağı üzerinde en etkin yazarlardan biri olan Viktor Hugo (1802-1885) ve 1824-1832 tarihleri arasinda yayınladığı Notre-Dame'ın Kamburu isimli ünlü eseridir. Viktor Hugo, kitabının sekizinci baskısında (1832), Fransızlara ulusal mimarlık sevgisini aşılamanın, sadece yazdığı romanın değil, yaşamının da asıl amacı olduğunu belirtmektedir. Hugo kitabında Fransa'daki çağdaş yapıların neden Fransa'nın tarihi anıtlarının özelliklerinden bağımsız olarak Yunan ve Roma mimarlığını taklit ettiğini sorgulamaktadır. Endüstrileşmeyle Ortaçağ sanatındaki dehanın kaybolduğuna değinen Hugo'ya göre çağdaş yapılarda Fransa'nın tarihi anıtlarının üslubu olan Gotik mimari üslübun tekrar ele alınması mimarlıkta yeni bir çı̆̆ır açacaktır (Levine, 1982b, s.139-140). Victor Hugo'nun bu görüşlerinin sadece Fransa'da değil, İngiltere'de de mimarlıkta neo-Gotik üslübun benimsenmesinde etkili olduğu, zamanla neo-Gotik üslubun neo-Klasik üsluba karşı yürütülen romantik bir savaş niteliği kazandığ 1 ve mimarlıkta ulusalcılığın neo-Gotik üslup ile doğduğu belirtilmektedir (Akın,

${ }^{34}$ Viollet-le-Duc üzerine yapılmış çalışmalar için bkz. (Tosun, 2008, s.229-225) 
2003, s.28). ${ }^{35}$ Kahramanı Paris'deki Notre-Dame Katedrali olan eserin yankılarıyla Ortaçağ yapıları ilgi odağ 1 olmuştur.
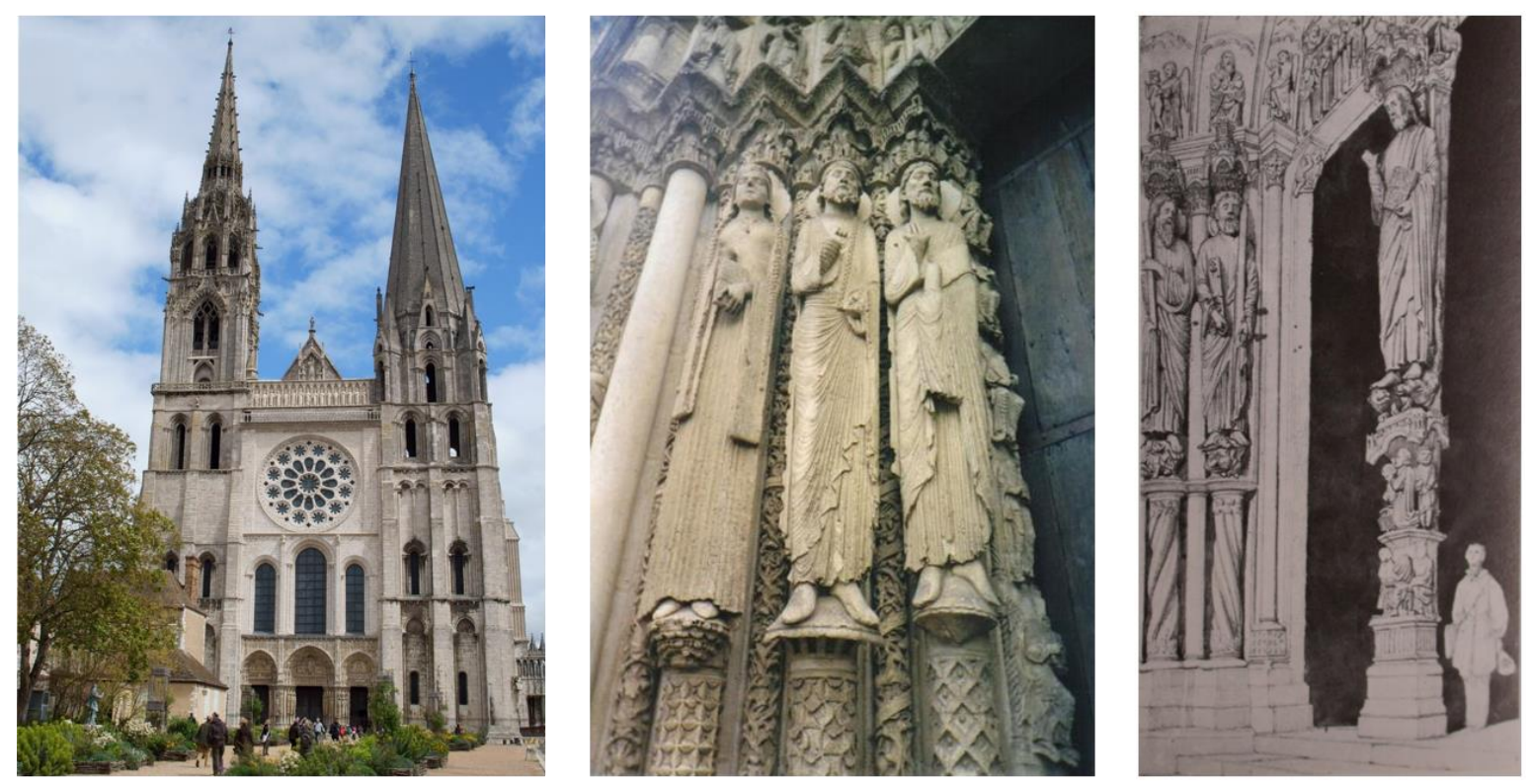

Resim 8: Chartres Katedrali giriş cephesi ve cephedeki heykellerden detay (Tosun, 2008, s. 152, r. 1-2), Viollet-le-Duc'ün otoportresi (Foucart vd., 1980, s. 34)

Viollet-le-Duc'ün mimari gezileri de, ilkine dayısı Delécluze ile birlikte çıktığı, bu yıllarda başlamıştır. 1831'de güney Fransa kentlerindeki 4 aylık gezisini, aynı yıl 1 ay kuzey Fransa kentleri; 1833'de 5 ay boyunca Fransa'nın çeşitli kentlerindeki gezileri takip etmiştir. Viollet-le-Duc'ün oğlu Eugène-Louis'nin torunu olan Geneviève Viollet-le-Duc, kendisiyle yapılan söyleşide, Viollet-leDuc'ün, 13. yüzyıl Gotik mimarlığın en önemli eserlerinden biri olan Chartres Katedrali'nin (11941252) kendisinde uyandırdığ 1 ilk çarpıcı etkiyi hayatı boyunca taşıdığını (Resim 8$)^{36}$ ve sadece Gotik üslubu değil, Romanesk üslubu da içine alan tüm Ortaçağ mimarlığını büyük bir merakla incelediğini belirtmektedir (1980b, s. 15). ${ }^{37}$ Hayatı boyunca her yere çizim defteri ve kalemiyle gittiği, gördüğü her yapı için çizim yaptı̆̆ belirtilen Viollet-le-Duc, bu geziler sırasında tarihi yapılar üzerine yaptı̆̆ 1 ayrıntılı mimari araştırmalarla mimari bilgi birikimini geliştirmiş; gezdiği yapıları anlamak için yaptığ 1 detaylı eskiz çizimlerle de önemli bir mimari belge birikimine sahip olmuştur. 1836-1837 y1lları arasında 6 ayını Roma'da geçirdiği 1.5 yıllık İtalya seyahatinden döndüğünde getirdiği 221 adet çizim ise bahsettiğimiz üzere yayınlanmıştır.

\footnotetext{
35 1851'de III. Napoléon Hükümeti ile Fransa dışına yerleşmiş ve Cumhuriyet yeniden kurulunca 1870'de Paris'e tekrar dönmüş olan Viktor Hugo ile Viollet-le-Duc'ün 24 Aralık 1876 tarihinde ve 1879 yılının Mayıs ayında (Viollet-le-Duc'ün ölümünden dört ay önce) birlikte akşam yemeği yedikleri belirtilmektedir.

${ }^{36}$ Fransız Gotik mimarisinin başyapıtı kabul edilen Katedral, Dünya Mirası listesine alınan (1979) ilk tarihi eserlerden biridir. Paris'in 80 km. dışında konumlanmış, Hz. Meryem'in (Hz. İsa doğarken giydiği) pelerinin burada korunuyor olması sebebi ile önce Fransa halkı, sonra tüm Batı Avrupa bağışları/vergileri ile inşa edilmiş, $105 \mathrm{~m}$. yüksekliği ile döneminin en yüksek yapısıdır. Romanesk temeller üzerine 13. yüzyıl Gotik üslubunda inşa edilen yapıyı çevreleyen uçan payandalar ilk defa bu yapıda planın bir parçası olarak tasarlanmıştır. En eski heykel programını barındırdığı; 'Chartres mavisi' olarak anılan vitrayların bu yapıya özgü olduğu ve özgün değerlerini günümüze kadar korumuş olduğu belirtilmektedir.

37 Yaşadığı dönemde tüm Ortaçağı kapsayan üslubun 'Gotik' olarak adlandırılması nedeniyle Viollet-le-Duc'ün zaman içinde Gotik üslupla özdeşleştirildiğini belirten Geneviève, bu bağlamda Viollet-le-Duc'ün Vézelay'daki Madeleine Kilisesi restorasyonundaki tutumunu örnekler: Gotik üslup özellikleri taşıyan kilise, restorasyonundan sonra, Viollet-leDuc’ün büyük ölçüde yaptığı Romanesk üsluptaki tamamlamalarla, Romanesk üslup özellikleri taşıyan bir yapı olmuştur.
} 
1837 yılında, ulusal birliğin vurgulaması ve ulusal belleğin yapılandırılması arzusu ile Ortaçağ dönemine ait anıtların belgelenmesi ve rölövelerinin çıkarılması için Commission des Monuments Historiques kurulmuş; ilk başkanı Ludovic Vitet ve dayısının yakın dostu olan yeni başkan Prosper Mérimée, Fransa' daki Romanesk ve Gotik üslupta inşa edilmiş olan mimari anıtların eskiz çizim ve rölövelerini yapması amacıyla Viollet-le-Duc'ü görevlendirmişlerdir. Viollet-le-Duc, 1838'de Paris'e döndükten sonra kendisine verilen bu görev sayesinde birkaç y1l süresince Fransa'nın tüm kentlerini gezmiş; Romanesk, Gotik ve Rönesans yapılarını detaylı eskiz çizimler yaparak incelemiş, tüm katedralleri detaylı çizimler ile belgelemiştir (Viollet-le-Duc, 1890a, s. 4). 1850'de 1 ay İngiltere'de, 1855-56 yıllar1 arasında bir y1l süre ile Almanya'da, ve bir süre Yunanistan'da kalarak kent kent dolaşıp, yapı yapı gezmiş; yapıların detaylı eskiz çizimlerini yapmış; Fransız mimarlığı ile karşılaştırmıştır.

Gezi araştırma ve gözlerine dair düşüncelerini anlattığı mektupların büyük bir çoğunluğu önce dönemin süreli yayınlarında daha sonra derlenerek kitap halinde yayınlanmıştır. Viollet-leDuc'ün bu mektuplardaki anlatım ve değerlendirmelerinin, 19. yüzyıl seyahlarının romantik anlatımlarından farklı olarak olağanüstü ve bilimsel gözlemler olduğu, özellikle kırsal kesimlere yönelik ilk bilimsel betimlemeler olduğu belirtilmektedir. ${ }^{38}$

Bu gezilerindeki ana amacının mimarlık tarihini öğrenmek ve Ortaçağ yapılarını anlamak olduğu mektuplarındaki anlatımlarından anlaşılmaktadır. Bu ülkelerdeki Ortaçağ yapılarını, kendi ülkesindeki Ortaçağ yapıları ile karşılaştırarak Fransa'ya özgü olan mimari özellikleri de belirlemeye çalışmıştır. Dönemin etkin mimarlık gazetelerinden biri olan Encyclopédie d'Architecture'da yayınlanmış olan bu mektuplarında Viollet-le-Duc Avrupa ülkelerinin yüzyıllar boyunca yapılarını koruyarak kendi mimari prensiplerini bugüne taşıdıklarını, yine bir Avrupa ülkesi olan ancak farklı bir dili konuşan Fransa'nın ise Fransız mimarlığının başyapıtlarını yapmış olan mimarlarının ortaya koyduğu mimari prensiplere sahip çıkmadığı için kendi ulusal mimarlı̆̆ını oluşturamadığını belirtmektedir. ${ }^{39}$ École Des Beaux-Arts'da verilen mimarlık eğitimini eleştirmekte, ${ }^{40}$ okulun, çağdaş mimarlıkta neo-Klasik mimarlığın biçimsel özelliklerinin tekrarlanmasına yönelik öğretiler vermesi nedeniyle Fransa'nın kendi topraklarındaki mimari mirası unutup, mimari kimliğini kaybetmiş olduğunu belirtmektedir. Bu nedenle, 'Fransa'nın ulusal mimarlığına tekrar kavuşması için Ecole des Beaux Art'ın eğitim sistemi değişmelidir' ${ }^{41}$ Viollet-le-Duc Roma' daki okula eğitim görmek için giden öğrencilerin iki yıl boyunca Roma'da kalmalarını da eleştirmektedir. Öğrencilerin, tek bir ülkenin mimarlığından ilham almalarını doğru bulmamaktadır. Öğrencilerin Roma'da bulundukları süre içinde Yunanistan, İstanbul, Kudüs, İspanya ve Afrika'ya mimari araştırma gezileri yapmalarının kişisel yeteneklerini geliştireceğini savunmuştur. Bu görüşlerini Güzel Sanatlar Akademisi Daimi Sekreteri M.Beulé'ye yazdığı mektubunda açıkça dile getirmiştir (1863, 213).

Viollet-le-Duc'e göre toplumların kendi ülkelerine ve yaşadıkları zamana uygun bir mimarlığa ihtiyaçları vardır. École Des Beaux-Arts'da ise öğrencilere bu anlamda mimarlık öğretilmemektedir. Öğrenciler neyi neden yaptıklarını bile sorgulama bilincinden yoksun, Klasik dönem anıtlarına yönelik arkeolojik çalışmalar yapmakta ve çizimlerle onların kopyalarını

\footnotetext{
${ }^{38}$ Ayrıntılı bilgi için bkz. (Géza Hajos, 1980)

${ }^{39}$ Prag'dan A. M. Adolphe Lance'a Eylül 1854'de yazmış olduğu (Viollet-le-Duc, 1856a, s. 43) ve (Viollet-le-Duc, 1856b, s. 141) mektubunda anlatmaktadir.

40 1856'da dönemin Fransa Devlet Bakanı yazdığı bir mektupta Viollet-le-Duc'ün mimarların yeniden organize edilmesi ve güzel sanatlar eğitiminin yeniden düzenlenmesi yönündeki başlattığı tartışmaları desteklediğini ve bu konularda acil olarak yenileme yapılması gerektiğini düşündüğünü belirtmektedir (Encyclopédie d'Architecture, 1856c, s. 3-4).

${ }^{41}$ École Des Beaux-Arts'da Antik Yunan ve Roma mimarlı̆̆ı oran ve düzenlerinin en iyi şekilde taklit edilmesine yönelik verilen derslerin dışında, aylık tasarım yarışmaları düzenlenmekte, böylelikle öğrencilere "Büyük Roma Ödülü" kazanmalarına yönelik deneyim ve bilgi kazandırılmaya çalışılmaktadır. Bu ödüle yönelik tasarımlar ise Güzel Sanatlar Okulu'nun neo-Klasik akımına bağlılı̆̆ının sembolü olarak değerlendirilmektedir (Levine, 1982a, s. 67-68). Akademi kendi öğretisini 1858 yılından itibaren Dictionnaire des Beaux-Arts (Güzel Sanatlar Sözlüğü) adlı sözlükle de yayınlamaya başlamışır (Arseven, 1998, s. 27-28).
} 
üretmektedirler. Oysa Viollet-le-Duc'e göre, mimarlık eğitiminde öğrencinin tartışma, mantıklı çözümler üretme ve sorumluluk alma bilincinin geliştirilmesi, mimari pratik yapmasını sağlamak gereklidir (Viollet-le-Duc, 1987, s. 385-388). Mimar öncelikle geçmişin önemli eserlerini analiz etmeyi, daha sonra kendi sentezini yapmayı öğrenmeli; ihtiyaca uygun bir mimari biçimlenmeyi kendi döneminin yapım malzemelerini kullanarak yapmalıdır (Summerson, 1963, s. 141). ${ }^{42}$

Nitekim, Ortaçağ mimarlığını anlamak için ne kadar kapsamlı çalışmalar yaptığı ve günümüz mimarlık tarihi araştırmalarında benimsenmiş bir yaklaşım ve yöntemle çalışmış olduğu şu sözlerinden anlaşılmaktadır;

\begin{abstract}
"Ortaçă̆ mimarllğ hakkında bir tarih yazmak istemek, imkansızı gerçekletirmeye çalışmaktır çünkü birçok halkın dini, politik, feodal ve sivil tarihlerini bir arada incelemek; çeşitli bölgeleri etkilemiş çeşitti ögelerin farkl derecelerdeki etkileşimini tespit etmek; bu etkileşimlerin bağlarını bulmak, karışımları incelemek ve sonuçlarını tanımlamak; bölgesel gelenekleri, halkların zevkleri ve göreneklerini, malzeme kullanımında uyguladıkları kuralları, ticari ilişkilerini, olayların doğal bir şekilde gelişmesine veya yapay bir şekilde belli bir yöne eğilmesinde etkili olmuş dahilerin varlıkların göz önünde bulundurmak; oluşmakta olan yeni bir medeniyetin durmak bilmeyen araştırmalarını takip etmek ve ortaçağın ansiklopedik, dini ve felsefi ruhuna girmek gerekir." (Viollet-le-Duc, 1854-68, s. 4-5).
\end{abstract}

Ülkesinin ulusal mimarlığının gelişmesinde bir kaynak olması için Viollet-le-Duc araştırmacıların ve mimarların Ortaçağ mimarlığını kolaylıkla inceleyebilecekleri bir eser hazırlamaya karar vermiş; Ortaçağ yapılarının kronolojik olarak rölöve çizimleriyle ${ }^{43}$ ve detaylarıyla tek tek sunulduğu ansiklopedi formatında 10 ciltlik bir kitap hazırlamıştır. ${ }^{44}$ Kendisini hem Fransa'ya hem de dünyaya tanıtan Dictionnaire Raisonné de l'Architecture Française du XI au XVI Siècle isimli bu ilk eseriyle Fransa'nın ortaçağ yapıları belgelenmiştir. 1854'de Viollet-le-Duc 40 yaşında iken ilk cildi yayınlanan eser, yayınlandığı tarihten itibaren büyük bir yankı uyandırmış, 1868'de son cildi yayınlanarak tamamlanan bu ansiklopedik kitap çeşitli ödüller almıştır. ${ }^{45}$ Özellikle katedral, kilise, şato gibi ortaçağ yapılarını kronolojik bir sırada çizimleriyle anlattığı bu eserini belki de tamamlaması düşüncesiyle 1858-1875 yılları arasında, Gotik döneminin mobilyalarına yönelik kapsamlı bir çalışma olan altı ciltlik Dictionnaire Raisonné du Mobilier Français, de l'Epoque Carlovingienne à la Renaissance (Karolenj Dönemi'nden ${ }^{46}$ Rönesans'a Kadar Fransız Mobilyalarının Açıklamalı Sözlüğü) adlı ansiklopedik kitap yayınlayarak Gotik döneme ilişkin tüm bilgi, belge ve düşünce birikimini araştırmacı ve uygulamacı mimarlara sunmuştur.

5000 sayfalık Dictionnaire, 515 terimin anlatıldığı sözlük ve gotik dönem yapılarının çizimlerinin yer aldığı ek olmak üzere iki bölümden oluşmaktadır. Sözlük bölümünde örneğin

\footnotetext{
${ }^{42}$ Ayrıntılı bilgi için bkz. 20 Aralık 1855 tarihli mektup (Viollet-le-Duc, 1856c, s. 4-11)

${ }^{43}$ Viollet-le-Duc'ün çizim tekniğine ilişkin ayrıntılı bir çalışma yapmış olan Martin Bressani, bu çizimlerin çoğunun yapıların mevcut durumlarını yansıtmadığını, Viollet-le-Duc'ün hayal gücünü çizimlerine kattığını, Dictionnaire Raisonné de l'Architecture Française du XIe au XVI $I^{e}$ Siècle yer alan tüm çizimlerin bu niteliği taşıdığını anlatmaktadır (2000a, s. 122).

${ }^{44}$ Bahsedilen bu eserinde Viollet-le-Duc'ün Güzel Sanatlar Akademisi üyelerinden Quatremère de Quincy (1755-1849)'nin 1785'de yayınlanmış olan Dictionnaire Méthodique de l'Architecture (Mimarliğın Metodik Sözlüğ̈̈)'den etkilemiş olduğu belirtilmektedir (Bergdoll, 1990, s. 12-16).

${ }^{45}$ Eserin yayınlandığı günden itibaren hem Fransa'daki hem de Fransa dışı ülkelerdeki uygulamacı, yazar ve araştırmacı mimarları ne kadar etkilediği Encyclopédie d'Architecture'de çıkan bir çok haber ve yazıdan izlenebilmektedir. Eser hem kendi ülkesinde hem de dünyada neo-Gotik üslubun mimarlığa uygulanışında en önemli kaynak olmuştur. Viollet-leDuc'ün Dictionnaire Raisonné nin 2. cildi için Académie des Inscriptions et Belles-Lettres'den ödül aldığı belirtilmektedir. (Encyclopédie d'Architecture, 1856b, s. 135). Viollet-le-Duc'ün yine bu eseri Académie des Beaux-Arts'dan ödül kazanmıştır. (Encyclopédie d'Architecture, 1861b, s. 153)

${ }^{46}$ Pepin le Bref adlı Fransız Kralı dönemi veya 18-19. yüzyıllarda Fransa'daki dönemi işaret eden Karolenj Dönemi için bu kelimenin ilk defa 19. yüzyılda Viollet-le-Duc tarafından kullanıldığı belirtilmektedir.
} 
'mimarlık' maddesi 336 sayfa boyunca, 'inşaat' maddesi ise 279 sayfa boyunca anlatılmaktadır. Dictionnaire Raisonné du Mobilier Français, de l'Epoque Carlovingienne à la Renaissance isimli yayınının ise ne kadar ayrıntılı olduğu şu şekilde ifade edilmiştir;

"Şato sahibesinin saç tuvaletinden, sevgilisinin yayına, sehpalı baldekenden yatağa

kadar, mimar bize ortaçağın tüm uğraşlarını tanıtmaktadır." (Togay, 1980a, s. 109).

Viollet-le-Duc, Dictionnaire 'in 1854'de yayınlanan ilk cildinin onbeş sayfalık önsözünde, bu eserle, mimari biçimleri değil, bu biçimlerin varoluş nedenlerini, bu biçimlerin arkasında yatan ana düşünceleri ve Ortaçağ toplumuyla uyumlu olarak gelişmiş olan Ortaçağ sanatının ruhunu açığa çıkarmayı amaçladığını belirtmektedir. Mimari mirasın değerini ise (1854-68);

"Yüzyılımız geçmişi özetlemeye çallşlyor; görünen o ki, geleceğe doğru bir yol açabilmek için nereden geldiğimizi iyi bilmemiz ve önceki yüzylların bize aktardı̆̆g bilgiyi almamız gerekiyor"'(s. 5), sözleri ile ifade eder.

Döneminin Gotik mimarlık üzerine yapılmış çalışmaları içerisinde Viollet-le-Duc'ün öne çıkmasının nedeni, Gotik mimarlığa romantik yaklaşımlardan farklı olarak benimsediği akılcı tutumudur. Viollet-le-Duc'ün Gotik mimarlık üzerine yaptığı bu çalışmaların amacı, diğer araştırmacılar gibi bu mimarlığı tekrar eden mimari biçimler üretmek değil, bu mimari mirasın akılcı modern yapılar tasarlamakta kaynak olarak kullanılması, bu yönde ana prensiplerin belirlenmesidir. Viollet-le-Duc, tarihi yapıların ana biçimlenme prensiplerini keşfetmeye çalışmış, Ortaçağ yapılarının strüktürel mantığını ve biçimsel geometrilerini analiz etmeye ve Ortaçağ mimarlığının akılcı prensiplerini belirlemeye çalışmıştır. Gotik mimarlığın ana prensiplerini anlamak için uyguladığı akılcı yöntem mimarlık tarihinde bir çı̆̆ır açmışıır. ${ }^{47}$ Ortaçağın mimari dilini, Dictionnaire kitabında, yapıları parça parça anlatarak anatomik bir çözümlemeyle, açıklamaya çalışması modern yapısalcılığın da öncüsü olmuştur (Damish, 1980, s. 93-99).

Viollet-le-Duc, bu düşüncelerini önce onun mimarlık düşüncelerinin anlaşılmasında çok önemli bir kaynak olan ünlü eseri Entretiens sur l'Architecture (Mimarlık Üzerine Konuşmalar), isimli kuramsal kitabıyla döneminin mimarlık ortamına, daha sonra genç nesile hitaben yazdığı hikaye kitaplarıyla topluma sunmuştur. Viollet-le-Duc'ün mimarlık tarihine yaklaşımını, mimariyi çözümleme metodunu, çağın ruhunu yansıtan bir ulusal mimarlığın tasarım mantı̆̆ını ve bu bağlamda yeni teknolojinin nasıl uygulanacağını anlattığı Entretiens dönemin mimarlarının esin kaynağı olmuştur. ${ }^{48}$

İlk cildi 1863 yılında, ikinci cildi 1872 y1lında iki cilt halinde yayınlanan kitap, her cildinde 10 'ar tane olmak üzere toplam 20 bölümden oluşmaktadır. Tarih boyunca gelişen çeşitli dönemlerin mimarlığının ve üsluplarının biçimlenme mantığını sorguladığı kitabının ilk cildi Viollet-le-Duc'ün mimarlık tarihi öğretisini sunmaktadır. İlk bölümünde ilkel yapıları; sonra sırasıyla Yunan mimarlığını, Roma mimarlığını, Bizans mimarlığını, Ortaçağda batı mimarlığının prensiplerini, Romanesk ve Gotik üsluplarının mimarlığını; mimarlığın zayıfladığı bir dönem olarak kabul ettiği özellikle Fransa'daki Rönesans dönemi mimarlığını son olarak da 19. yüzyıl mimarlığını anlatmaktadır.

Viollet-le-Duc yine on bölümden oluşan kitabının ikinci cildinde ise, ilk üç bölümde mimarlık tarihinden verdiği örneklerle taş yapım sistemini, tuğla yapım sistemini ve kamu yapıları tasarımları sunarak bahsettiğimiz yapım sistemlerine çağın yeni malzemesi olan demirin nasıl

\footnotetext{
${ }^{47}$ Laurent Baridon, 1996 yılında yayınlanan L'imaginaire Scientifique de Viollet-le-Duc isimli kitabında Viollet-le-Duc'ün Dictionnaire kitabı üzerinde bir araştırma yapmış; onun akılcılığını modellemeye, bilimselliğini ve dehasını ortaya koymaya çalıştığı bu araştırmasında; onun strüktürel rasyonalist olduğunu belirtmiştir (Eigen, 1999, s. 225).

${ }^{48}$ Viollet-le-Duc'ün modern mimarlığa kaynak olmasının sebebi işlev, biçim, strüktür ve süslemeye ilişkin kurduğu ilişkiler ve teknolojik gelişmeleri mimarlığa yansıtmasıdır (Murphy, 2000, s. 9).
} 
eklenebileceğini anlatmış; dördüncü bölümde ise mimarlık eğitimi hakkında görüşlerini sunmuştur. Kitabın beşinci bölümde çeşitli coğrafyalardaki mimari üslupların mimari süsleme elemanlarını ele almakta, altıncı bölümde bunlardan, anıtsal yapılarda süsleme elemanı olarak kullanılan, heykelleri anlatmaktadır. Viollet-le-Duc kitabın devam eden üç bölümünü konut mimarlığına ayırmıştır. Bu üç bölümde ilk olarak Venedik saraylarından, daha sonra Fransa' daki kentsel ve kırsal yerleşimlerdeki konutlardan, şatolardan ve Paris'teki apartmanlardan çeşitli örnekler vererek bunların mimari özelliklerini ve işlevsel programlarını anlatmış; özellikle konutlara ayırdığı ikinci bölümden itibaren bahsedilen yapı türlerinin yapım sistemlerinde demirin nasıl kullanılabileceğini detaylı çizimlerle göstermiştir. Son bölümde yaşadığı çağın, yani 19. yüzyılda, Avrupa'da mimarlığın durumunu ve Fransa'daki mimarların yaklaşımlarını değerlendirmiştir.

Viollet-le-Duc, hem bu kitabı hem de mimarlığa bakışı şekillendirmeye çalıştı̆̆ hikaye kitaplarıyla okurlarına aynı zamanda mimarlık eğitimi de vermiş̧tir.Viollet-le-Duc'ün bu yaklaşımı sayesinde 19. yüzyılda Fransa mimarlığındaki gotik hareket İngiltere mimarlığındakinden farklı olarak anti-tarihsel ve geleceğe bakan bir yaklaşım geliştirmiştir.

Viollet-le-Duc'ün altmışlı yaşlarında, hayatının son altı yılında, genç nesile hitaben yazdığı 5 hikaye kitabı sırasıla; 1873'de Histoire d'une Maison (Bir Evin Tarihi), 1874'de Histoire d'une Forteresse (Bir Kalenin Tarihi), 1875'de Histoire de l'Habitation Humaine (İnsan Yerleşimleri Tarihi), 1877 'de Histoire d'un Hôtel de Ville et d'une Cathédrale (Bir Belediye Sarayı ve Bir Katedralin Tarihi), 1879'da Histoire d'un Dessinateur : Comment on Apprand à Dessiner (Bir Ressamın Hikayesi: Resim Çizmek Nasıl Öğrenilir)'dir. Bu kitaplarıyla okuyucuların mimarlığa bakışını yönlendirmeye çalışmakta, topluma yönelik mimarlık eğitimi vermekte; hikayelerinde evrensel bir yaklaşımla mimarlığı anlatmaktadır. (Bressani, 1989, s. 329; Hearn, 1995; Viollet-leDuc, 1980b s. 17). Hikayeler özetle şu şekilde anlatılır;

Histoire d'une Maison isimli hikayede, Paul de Gandelau isimli bir okul öğrencisi FransaPrusya savaşı nedeniyle okullar tatil olunca; eşinden ayrılan kız kardeşi için bir ev tasarlar. Ev, kırsal bir yerleşimdeki aile malikanesi içinde inşa edilecektir. Paul, mimar olan kuzeni Eugene ile birlikte evi tasarlar ve yapımına yardım eder. Hikaye hem mimari tasarım sürecini hem de yapım aşamalarını anlatmaktadır.

Histoire de l'Habitation Humaine isimli hikayede, Doxius ve Epergos adında iki kahraman, Orta Asya, Mısır, Roma, Suriye, Hindistan, Uzak Doğu ve İskandinavya ülkelerine seyahat etmekte ve gördükleri yerlerin konut mimarisi üzerine tartışmaktadırlar. Doxius tutucu ve değişime karşı olan bir karakter iken, Epergos ise gelişimi ve değişimi destekleyen bir karakterdir. Kitap, Viollet-leDuc'ün Fransa dışındaki ülkeleri gezmeye olan düşkünlügünü de yansıtmakta, ve yerel konut mimarisinin değerini anlatmaktadır. 27 bölümden oluşan kitapta dokuzuncu bölümde teokrasi toplumu Mısır uygarlığı, 18. bölümde Roma İmparatorluğu ve 27. bölümde Rönesans dönemi Fransız krallığı anlatılmakta; bu tarihsel süreç içinde taş yığma yapıdan ahşap iskelet sisteme geçiş gözler önüne serilmektedir. ${ }^{49}$

Nasıl çizim yapılacağını anlattığı Histoire d'un Dessinateur isimli hikayede, bir bahçıvanın 11 yaşındaki oğlu küçük Jean'ın görsel analiz yeteneği bir yapım ustası olan M. Majorin'i etkiler ve Majorin çocuğun eğitimini üstlenir. Majorin çocuğa sırasıyla basit geometriyi, doğadaki çiçekleri resmetmeyi, perspektif çizimi yapmayı, çizimde gölgelendirme metodunu, trigonametri, anatomi ve jeoloji bilgisi öğretir. Hikayesinde bu öğrenim sürecini anlatan Viollet-le-Duc, kendisinin çizim yapmayı nasıl kendi kendine öğrendiğini de açıklamaktadır. Viollet-leDuc'e göre nasıl çizim yapılacağını öğrenmek beyni en çok geliştiren yöntemdir, bilgiye ulaşmanın yolu ise nasıl göreceğini

\footnotetext{
${ }^{49}$ Viollet-le-Duc'e göre, insanlar ve doğa çizgisel bir gelişim göstermektedir. İnsanlar, doğa ile mücadele ettikleri ölçüde doğayı ve kendilerini geliştirmektedirler. Bu bağlamdaki gelişimi kısaca şu şekilde anlatmaktadır: Antik Mısır uygarlığında Geometri sanatı keşfedilmiş; Antik Yunan uygarlığında sanat özgürleşmiş; Roma İmparatorluğu'nda ise sanat devlet yönetimi altına alınmıştır. Bu kitapla ilgili ayrıntılı anlatımlar için bkz (Bressani, 1989, s. 327-350).
} 
bilmekle başlamaktadır. Kitabın sonunda Jean, öğrendiklerini öğretmek için bir okul açmayı düşünmektedir. Şehirli bir adamın bir köylü çocuğa perspektif, geometri, ölçü gibi bilimleri öğrettiği Histoire d'un Dessinateur adlı kitabında güzel sanatlar ile uygulamalı sanatlar arasında ayırım yapmadan sanatçıyı ilk defa bir mimar-mühendis olarak tanımlaması Fransa'da 1882'de Dekoratif Sanatlar Birliği'nin, 1887'de Süsleme Sanatları Okulu'nun kurulmasına esin kaynağ 1 olmuştur. (Durant, 1980, s. 30-33).

\section{Mimari Restorasyon Uygulamaları}

Viollet-le-Duc'ün, Pierrefond Şatosu kadar büyük bir şato olan Bonaguil Şatosu'nu, yıkılmaktan kurtarmak için satın alıp, devlete vermesi, onun hem Ortaçağ yapılarına hem de bu yapıları korumaya yönelik sevgisini ve ciddiyetini açık bir şekilde ortaya koymaktadır (Viollet-leDuc, 1980b, s. 16). Viollet-le-Duc'ün, giriş bölümünde bahsettiğimiz, çoğunluğunu Ortaçă̆ yapılarının oluşturduğu tüm restorasyonlarını anlatmak, konumuzun çerçevesi dışına çıkan kapsamlı bir araştırma gerektirmektedir. Çalışmamızda, konumuz çerçevesinde, Viollet-le-Duc'ün mimari restorasyona yaklaşımı restorasyonlarından önemli birkaç örnek üzerinden sunulmaya çalışılmaktadır. Restorasyonlarında aldığı koruma kararları, mimari koruma yaklaşımını örneklemektedir. Araştırmacılar tarafından en önemli mimari restorasyonları olarak kabul edilen çalışmaları arasında şunlar sayılabilir; Vezelay'da Madeleine Kilisesi (1840-1862), Paris'te NotreDame Katedrali (1845-1864) ve Sainte-Chapelle Kilisesi, Saint-Denis Katedrali (1851-1879), Carcossone kenti surlar1 ve Carcossone'da Saint-Nazaire Kilisesi (1852-1879), Amiens Katedrali (1850-1875), Reims Katedrali (1861-1873), Toulouse'da Saint-Sernin Kilisesi (1860'lar-1880'ler), Clermont- Ferrand Katedrali, Pierrefonds Şatosu (1857-1885), Coucy Şatosu (1856-1866, 1871-), Avinyon kenti surlar1 (1860-1868) ve Lozan Katedrali (1874-1910) (Bercé, 1996, s. 594; Erder, 1972, s. 67-70) ${ }^{50}$.

Viollet-le-Duc, Commission des Monuments Historiques başkanı Prosper Mérimée'nin görevlendirmesiyle 1840 yılında henüz 26 yaşında iken, ilk mimari restorasyon çalışmasına Vézelay'daki Madeleine Kilisesi'yle başlamış, kısıtlı bir bütçe ile sürdürdüğü restorasyon 1862'de tamamlanmıştır (Resim 9). Restorasyon öncesinde 12. yüzyıl Romanesk ve Gotik cephe özelliklerine sahip olan Madeleine Kilisesi bir dönem terkedilmiş, bu sırada büyük ölçüde yıkılmış ve strüktürel anlamda zor ayakta durabilen bir yapıdır. Viollet-le-Duc yaptığı restorasyonda orta nefe oturttuğu uçan payandalarla destekleyerek yapıyı sağlamlaştırmış; yapının yıkılmış olan kısımlarını Romanesk üslupta tamamlamış; büyük ölçüde zarar görmüş olan ana portali özgün ikonografisine uygun olarak yenilemiş; böylece üslup birliği sağladığı yapıya yeni bir görünüm kazandırmıştır. ${ }^{51}$

\footnotetext{
${ }^{50}$ Restorasyonlarını yaptığı bu yapıların bazılarının heykel, mobilya, vitray tasarımlarını da yapmıştır. Ayrıntı için bkz. (Tosun, 2008, s.208-209)

${ }^{51}$ Yapının restorasyonuna ilişkin ayrıntılı bilgi için bkz. (Murphy, 2000)
} 

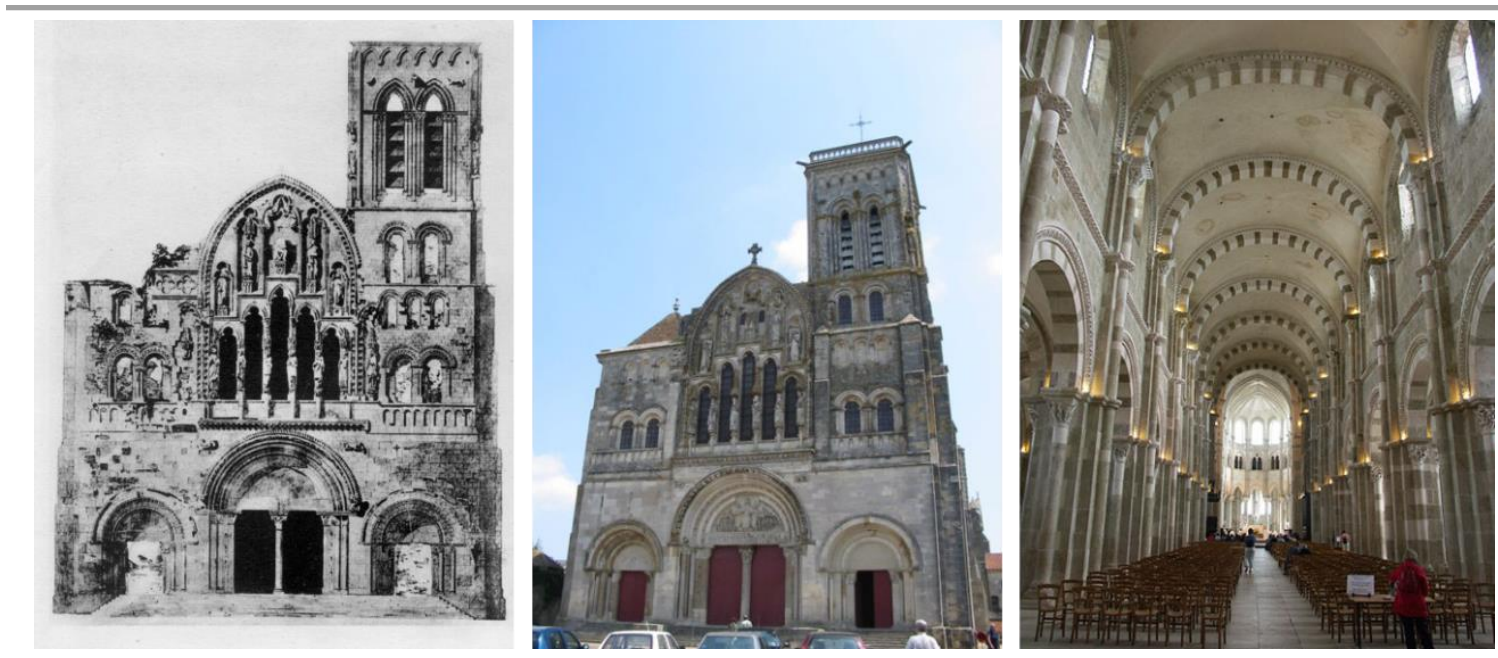

Resim 9: Viollet-le-Duc'ün Vézelay'daki Madeleine Kilisesi’nin (restorasyon öncesi) 1840 tarihli çizimi (Foucart vd., 1980, s. 19) ve restorasyon sonrası görünümü (Tosun, 2008, s. 154, r. 4-6)

$\mathrm{Bu}$ projedeki başarısı sonrasında Viollet-le-Duc, Paris'deki Sainte-Chapelle Kilisesi'nin restorasyon çalışmaları için ikinci müfettiş tayin edilmiş, birinci müfettiş olan Lassus ile bu çalışma sırasında tanışmış ve birlikte 1843'de katıldıkları Paris Notre-Dame Katedrali için açılan onarım yarışmasını kazanmışlardır. Victor Hugo'nun romanın kahramanı olan Notre-Dame Katedrali'nin restorasyonuyla (Resim 10) adını duyuran Viollet-le-Duc, bu projede birlikte çalıştığı Lassus'nün hem mimari restorasyon anlayışından hem de mimarlık üzerine düşüncelerinden etkilenmiştir. Lassus, $1845^{\prime}$ de Annales Archéologiques gazetesinde yayınlanan makalesindeki görüşleriyle tarihi anıtların restorasyonuna ilişkin bilimsel bir metod sunmaktadır. Onun, mimari yapı restorasyonunda mimarın amacının bilimsel bir yaklaşımla yapıyı korumak ve sağlamlaştırmak olduğu ve yapıya bir ek yapma mecburiyetinde kalırsa mimarın öncelikle yapacağ böylelikle yapının biçim ve malzemesine sadık kalması gerektiği yönündeki düşünceleri Viollet-leDuc'ün tarihi anıtlara yaklaşımında temel olmuştur (Jokilehto, 1999, s. 139).
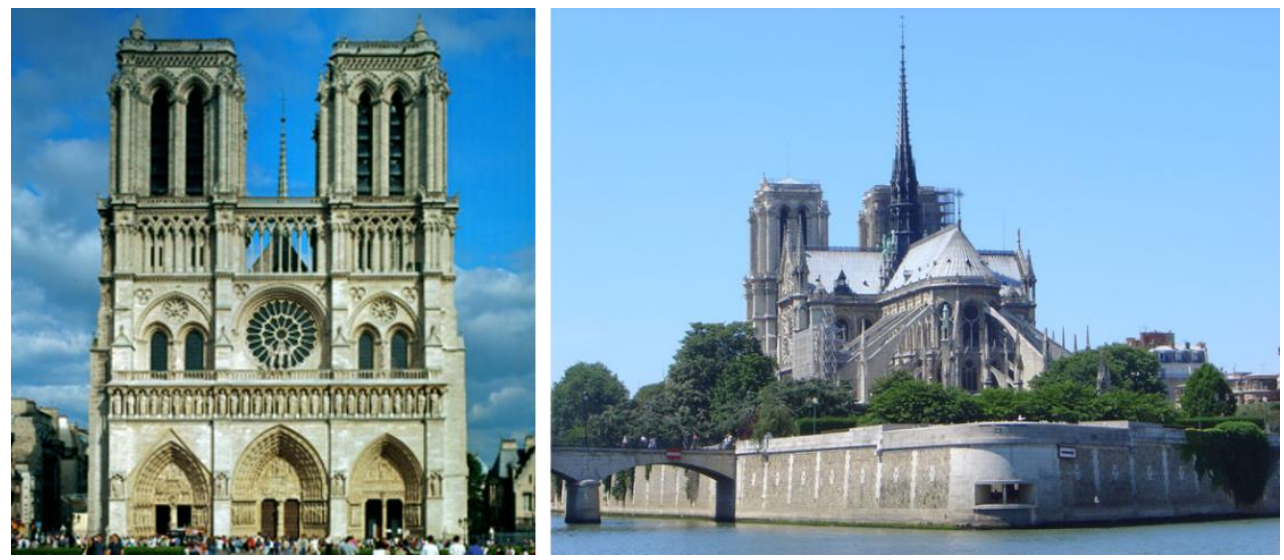

Resim 10: Notre-Dame Katedrali giriş ve arka cephesi (Tosun, 2008, s. 156, r. 7-8)

Viollet-le-Duc, bakanlığa sunduğu, Notre Dame Katedrali restorasyon projesi eki raporunda (1843); 'yapıya yüzyılların tahribatından daha çok zarar verebileceği için, restorasyon yerine sağlamlaştırma yapılması, heykel ya da silme eklenmemesi' yönündeki görüşleri anlamakla birlikte, 'hiç bir yararı olmayan bir kalıntı ile karşı karşıya kaldığımızda'; 'sanatçının sadece sağlamlaştırması, koruması değil, gayet temkinli restorasyon çalışmaları yaparak binaya yoksun 
bırakıldiğı olanca zenginliği ve parılttyı yeniden kazandırmak için elinden gelen herşeyi yapması gerektiği; kendisine emanet edilen anıtın ayrıntılarının ilgi çekici yanını ve sunduğu görünüs birliğini işte ancak böyle koruyup, geçmişi aktarabileceği' yönünde görüşlerini dile getirmektedir. Ona göre sanatçı 'restore etmek istediği eserin ortaya çıkmasını yöneten düşünceyi yeniden bulmalı; kendi beğenisini bir tarafa bırakıp, varolmayan o çağın sanatına boyun eğmelidir (Viollet-le-Duc, 2019, s. 19-21).

Ayrıntılı bir tarihi araştırma ile Paris Katedrali'nin yapı bölümlerini tarihlendiren Viollet-leDuc, yapıda üç ana dönem olduğunu (12., 13., 14. yüzyıl); bunlardan geç olan dönemdeki ek/müdahale/değişikliklerin yapıda nem problemi yaratmakla birlikte yapı özgünüyle orantılı olmadıklarını ve daha geç dönemlere (16., 17, 18., 19. yüzyıl) ilişkin benzer tespitlerini anlatmaktadır. 'Güzelliği ile dikkat çeken böyle bir eseri tamamlamak fikrinde olmamakla' birlikte; 'güzel katedralimize bütün ihtişamın yeniden kazandırmak ve elinden alınan zenginliklerin hepsini geri vekmek' yönündeki ana prensip kararını ve bu karara istinaden yapacağ1 restorasyon müdahalelerini açıklamaktadır. Örneğin, Paris Katedrali'nin içini ve dışını süsleyen alçakkabartmaların (Resim 11) döneminin üslubunda gerçekleştirebilecek ustalar artık bulunmadığı için, restorasyonlarının gerçekleştirilmesinin imkansız olduğunu; hem bu heykellerin hem de yenilenmesi gereken vitrayların, aynı çağa ait benzer anıtlardan (Chartres, Reims, Amiens vb.), taklit edilmeleri mümkün olmayacağı için, kopyalanacağını belirtmektedir (Viollet-le-Duc, 2019, s. 27-77).
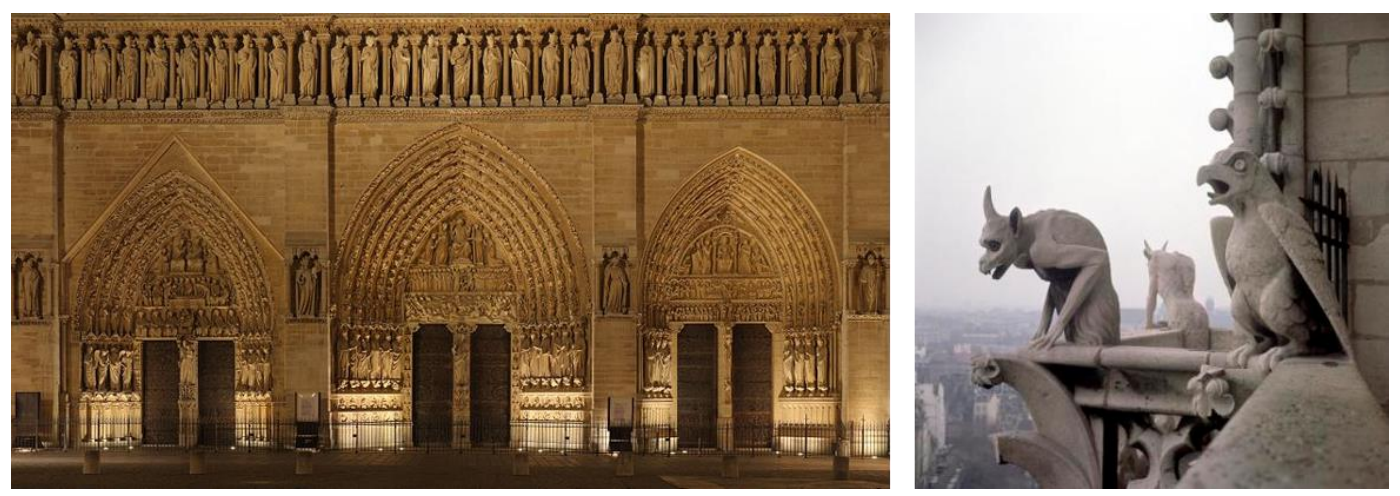

Resim 11: Notre-Dame Katedrali giriş cephesinde yer alan heykeller ve Viollet-Le-Duc'ün NotreDame Katedrali için tasarladığı çörtenler (Tosun, 2008, s. 157, r. 9-10)

Viollet-le-Duc'ün Languedoc'daki Carcassonne kentinde 1852'de başladığı restorasyon çalışmaları yaşamının sonuna kadar devam etmiştir. Büyük ölçüde yıkılmış olan sur duvarlarını restorasyonda yeniden inşa eden Viollet-le-Duc; sur duvarlarına yapının hiç bir döneminde sahip olmadığı bir strüktür olan mazgallar eklemiştir (Resim 12).

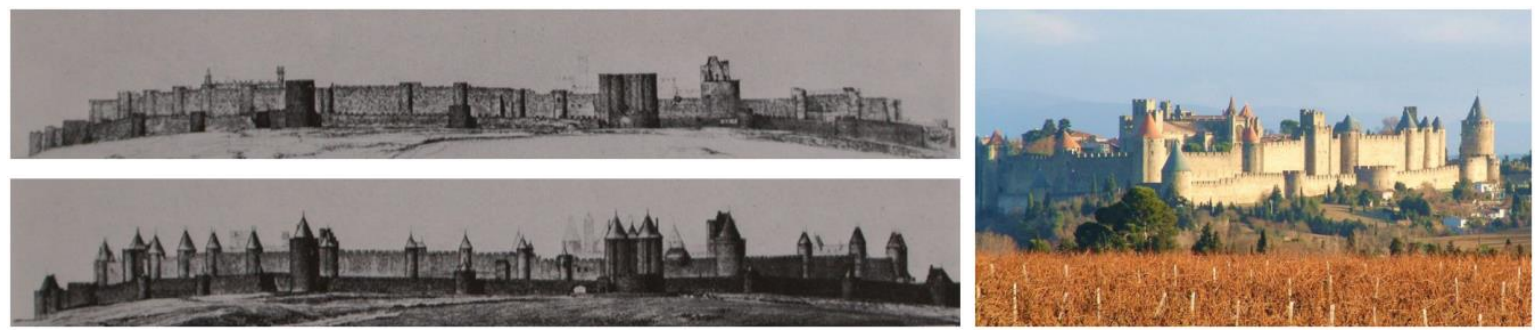

Resim 12: Carcassonne Surları restorasyonu öncesi ve sonrası (Foucart vd., 1980, s. 115; Tosun, 2008, s. 159, r. 12)

Viollet-le-Duc, Carsassone surlarında olduğu gibi büyük ölçüde yeniden inşa etmiş olduğu Pierrefonds Şatosu restorasyonunda Şatoyu İmparator III. Napoleon ve eşi Eugénie’nin özel konutu 
olarak düzenlediği için iç mekanların romantik bir havaya sahip olmasına çalışmıştır. Şatonun tüm mobilyalarını da tasarlayan Viollet-le-Duc'ün, bu mobilyalardaki, özellikle de sandalye ve koltuklarda kullandığı bitkisel motifler Art Nouveau'nun habercisi olarak nitelendirilmektedir (Bercé, 1996, s. 597; Elliot, 1989, s. 8). Cephede görülen timsah şeklindeki heykelsi çörten ise, onun mimari süslemeye yaklaşımını ve süslemeyi ancak mimarinin işlevsel ya da strüktürel elemanlarıyla bir bütün olacak şekilde kullandığını gösteren güzel bir örnektir. (Resim 13-14).
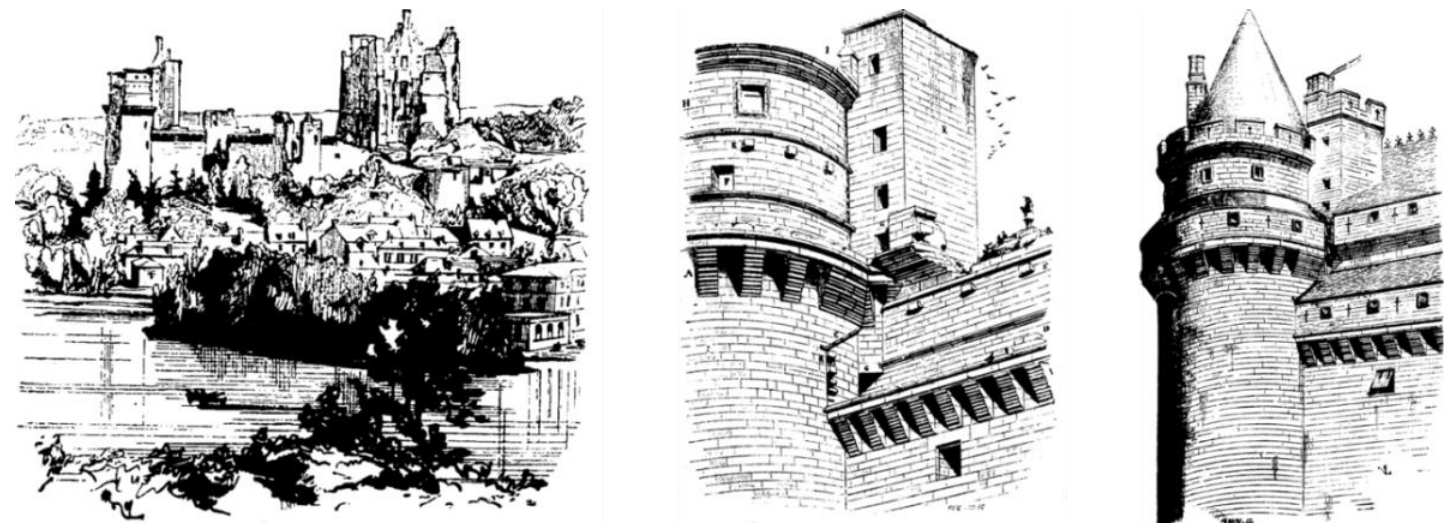

Resim 13: Viollet-le-Duc'ün Pierrefonds Şatosu'nun restorasyon öncesini ve sonrasını gösteren çizimleri (Viollet-le-Duc, 1857)
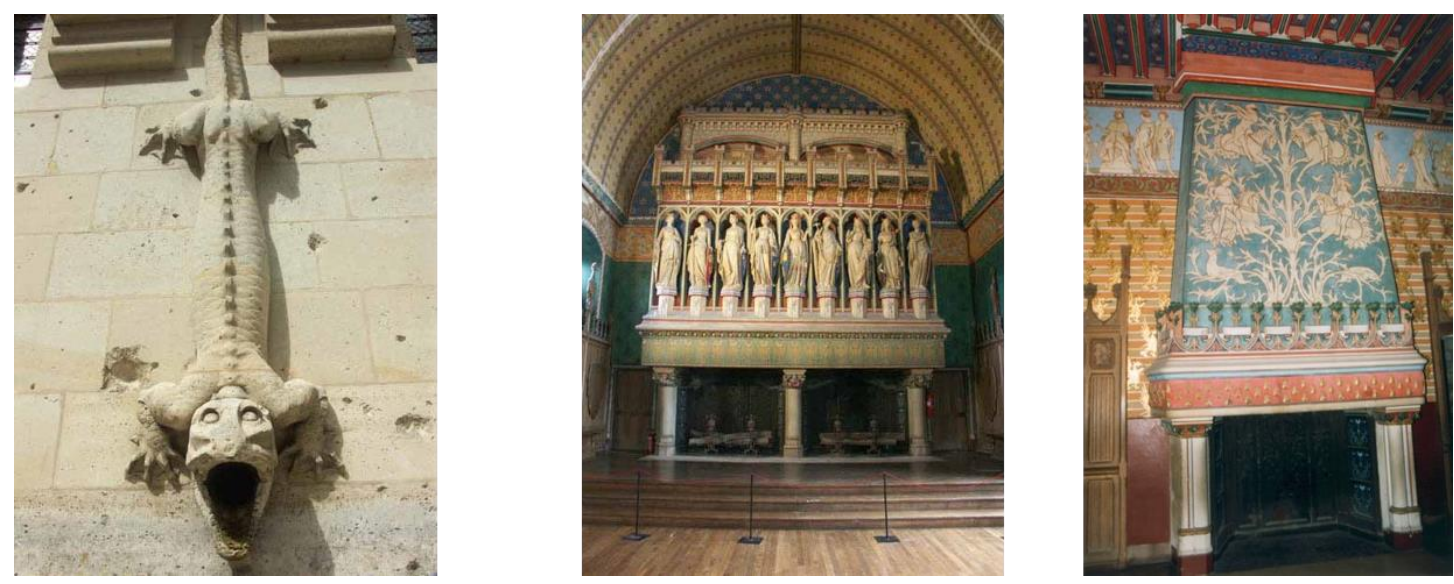

Resim 14. Viollet-le-Duc'ün Pierrefonds Şatosu için çörten ve Napoleon ile eşinin odaları için şömine tasarımları (Tosun, 2008, s. 163, r. 18-20)

Toulouse'daki Saint-Sernin'de Viollet-le-Duc yapının zaman içinde tahribatla yokolan süsleme elemanlarını, yapı çevresindeki anıtlarda gördüğü süsleme elemanlarına uygun olarak yeniden yapmıştır (Resim 15). Ancak süsleme elemanlarının bir tahribat nedeniyle yok olmadığı, aslında özgün yapıda da tamamlanmadan bırakılmış olduğu tespit edilince, Viollet-le-Duc'ün yaptığı bu eklerin kaldırılması gündeme gelmiştir (Clark, 1989, s. 357). Ocak 1978'de Tarihi Anıtlar Yüksek Komisyonu'nda Toulouse kentindeki St. Sernin Katedrali ile St. Raymond'un Koleji incelenmiş ve Viollet-le-Duc'ün yapmış olduğu ekler hem yapı hem de insanlar için tehlikeli bulunarak kaldırılmıştır. Katedral, Viollet-le-Duc'ün restorasyona başlamadan önce yapmış olduğu rölövelere uygun olarak 1860 öncesi durumuna getirilmiştir (Togay, 1980a, s. 109-110; 1980b, s. 153). Buna karşın, 1848'de Toulouse'daki Jacobin Kilisesi cephesi restorasyonu ise 1960'larda en doğru restorasyon uygulamalarına örnek olarak gösterilmektedir (Clark, 1989, s. 358). 

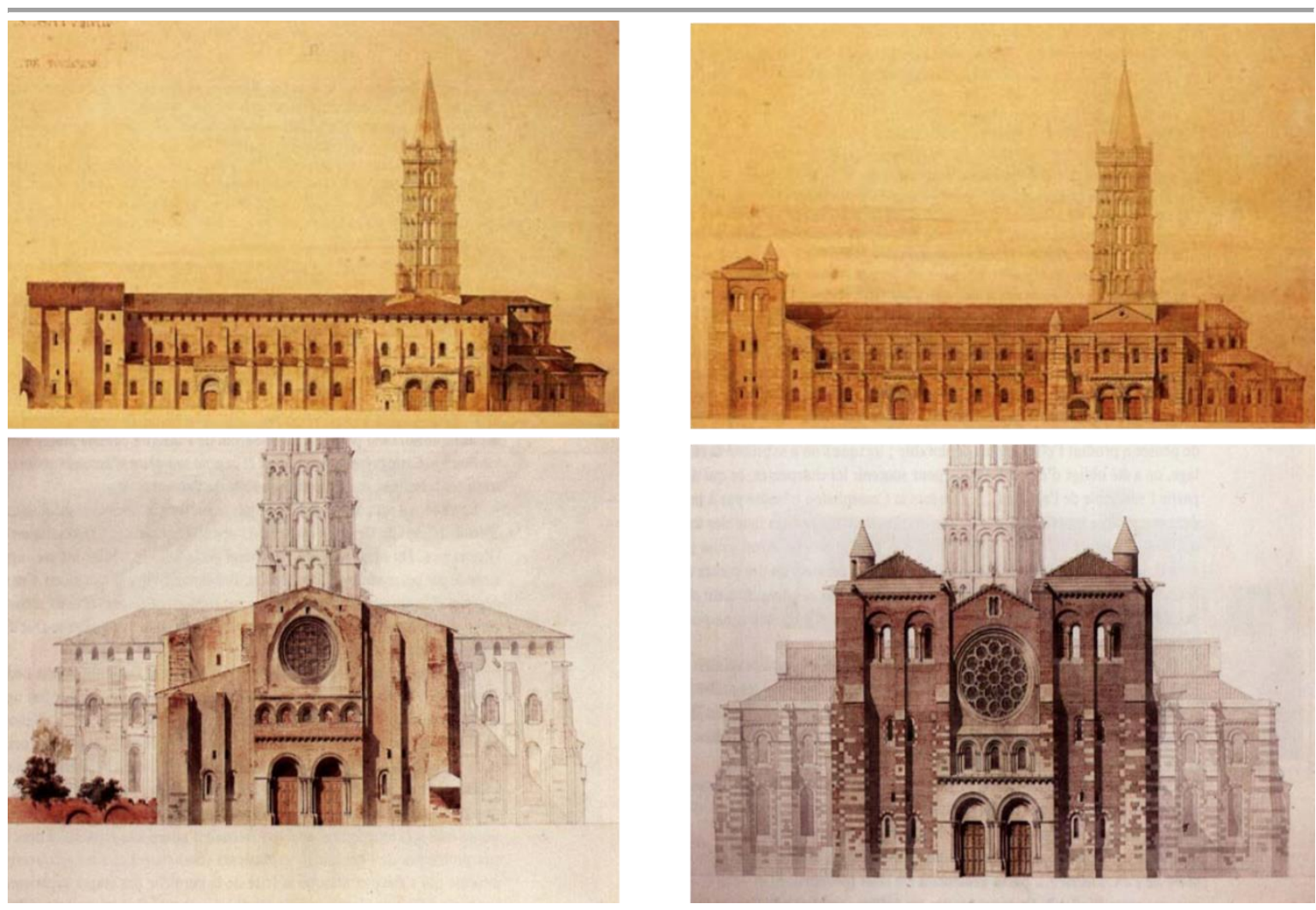

Resim 15: St. Sernin, restorasyon öncesi (sol), Viollet-le-Duc'ün restorasyonu sonras1 (saintraymond.toulouse.fr, 2021)

Viollet-le-Duc, Dictionaire eserinde 'proportion' (oran/orant1) maddesinde bu terimi 'bütün ile bölümler arasındaki gerekli ve mantıksal ilişkiler' olarak tanımlamaktadır. Kendi ifadesi ile; 'oranlar ile boyutları birbirinden ayırt etmek gerekir. Boyutlar, yükseklikleri, genişlikleri ve yüzeyleri verir; oysa oranlar bu bölümler arasında, bir yasa uyarınca kurulan göreli ilişkilerdir, bölümler arasında armonik bir ölçek, değişken ilişkiler arasındaki karşılıklı bağlardır'. Oranların körükörüne bir yöntem yada formül olmadığını; Mısırlı, Yunanlı, Romalı, Bizans ve Gotik mimarlar tarafından geometriden türeyen bazı yasaların 'boşluklar ile doluluklar, yükseklikler ile genişlikler, yüzeyler ile cephe görünüşleri arasındaki ilişkilerden türeyen yeni biçimler oluşturduklarını; geometrinin alnında kalan bu ilişkilerin dikkatle incelemeyi gerektirdiğini, mimarliğın kutsal bir oranlar sisteminin kölesi olmadığını, yeni oran iliş̧kileri ile durmadan yenilenen, sonsuz çeşitlilikte uygulama, geometri yasası bulunabileceğini, orantıları mimarlıkta organik ve inorganik doğada olduğu gibi geometriden doğduğunu Entretiens kitabının 9. Bölümünde anlatmış olduğuna' işaret etmektedir. ${ }^{52}$ Mimarlıkta oranların geometriden türeyen stabilite yasalarına dayandığını, üçgenin de bu anlamda en mükemmel şekil olduğunu ve Ortaçağ ustalarının orantı yasalarını, stabilite yasalarına uygun olması için, önce üçgenleri kullanarak belirlediklerini belirtir. Mimarlıkta sayısız ayrıntıda $45^{\circ}, 60^{\circ}$ ve $30^{\circ}$ lik çizgilerin kullanıldığını; buna bağlı olarak da 'Ortaçă̆'daki mimarların orantı oluştururken -dik açılı ikizkenar üçgen, Mısır ikizkenar üçgeni (yani tabanı dörde bölünen, tabanın ortasından tepeye çekilen dik çizginin iki buçuğa bölünebildiği üçgen ve eşkenar üçgen- (Resim 16, solda sırasıyla A, B, C üçgenleri) kullandıklarını', böylelikle ahenkli oranlar elde ettiklerini

\footnotetext{
${ }^{52} \mathrm{Bu}$ maddeyi Entretiens yayınlandıktan sonra, yani 1863 yılından sonra yazmış olmalıdır.
} 
anlatmakta, ${ }^{53}$ 'bu üçgenlerden bir tanesinin içine yerleştirilen binanın mükemmel bir stabiliteye sahip olacağını' belirtmektedir (Viollet-le-Duc, 2020, s. 11-17).
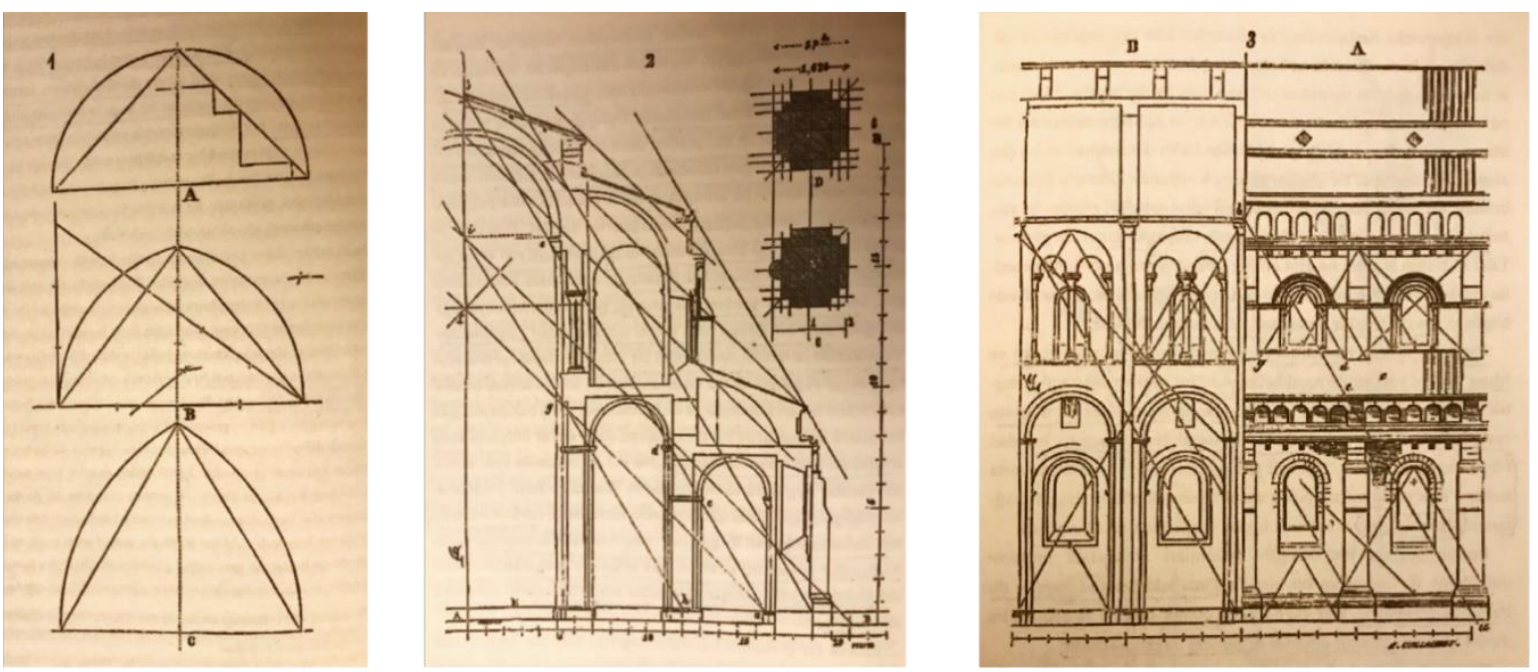

Resim 16: Viollet-le-Duc'ün üç üçgenine ilişkin çizimi ve St. Sernin'in tasarımının, yapı kesiti ile iç ve diş cephe görünüşleri üzerinde, bu üçgenlere oturduğunu gösterdiği çizimleri (Viollet-le-Duc, 2020, s. 16, 22, 25)

Viollet-le-Duc, 'proportion' terimi anlatımına, Ortaçağ yapı tasarımlarının bu üçgenlere nasıl oturduğuna ilişkin çizimlerle açıklamalı örnekler vererek, devam eder. Örneğin, St. Sernin Kilisesi'nin, (Resim 16) restorasyonu sırasında, çatısını tamamen değiştiren ağır ekleri kaldırıp, rölövesini çıkarttıklarını; yapı izlerinden örtüyü ve eski kornişlerin yerini tespit ettiklerini; temizleme çalışmaları sırasında 'gördükleri güzel oranlar yanında bütün binanın sergilediği ahenk karşısında şaşkınlı̆̆a kapılıp; bunun nedenini ögrenmek istediklerini' anlatmakta ve 'bu kadar geniş alana yayılan, çok ayrı bölümlerden oluşan bir binanın sadece raslantı ya da duygu sayesinde böyle özelliklere sahip olamayacağına' dikkat çekmektedir. Kilise'nin, 'süslemeden yardım alınmadan', kütleleri ustaca dengelenmiş bir tasarım olduğunu; 'gayet bilgili, sanatına derinden bağll, oranlar konusunda çok gelişmiş ilkelere sahip bir mimar tarafindan, dik açıl ikizkenar ve eşkenar üçgenlerin geometrisine oturan uzunluk, yükseklik ve genişliklerle' içeriden dişarıya doğru belirlenmiş bu orantı sisteminde tasarlandığını Resim 16'daki çizimler üzerinden anlatmaktadır. Yapı cephesindeki mimari elemanların da bu üçgenleri oluşturan çizgilere göre konumlanması sonucunda parçalar ile bütün arasında belirli bir geometrik oran oluştuğunu ifade etmekte, armoni açısından çok güçlü olması sebebiyle bu oranı 'billurlaşma ilkesi' olarak adlandırmaktadır. Viollet-le-Duc, yine kendi ifadesi ile , 'yapının, niteliksiz malzemeler kullanan kaba işçiler tarafindan 16. yüzyılda yapılan eklemelerle ahenginin bozulmuş, yozlaştırlmış olduğunu'; yapıyı bu ek ve süslemelerinden arındırarak: 'binanın, restore edildikten sonra, daha doğrusu genel biçimini yozlaştıran gereksiz parçalardan kurtarlldiktan sonra.... özenle inşa edilmesiyle, heykel ve silmelerinin zenginliğiyle ve ayrıntılarıyla değil, oranlar arasındaki ilişkileriyle halkın dikkatini çeken' bir eser haline geldiğini anlatmaktadir (Viollet-le-Duc, 2020, s. 17-24).

'Gotik denilen tarzda binalar inşa etmeye kalkışan mimarların.... kompozisyonlarını geometrik bir yönteme başvurmadan gerçekleştirmek' istediklerinde sayısız güçlükle karşılaşacaklarını; stabilite açısından güvenilir koşullara ulaşamayacaklarını; 'büyüleyen ve şaşırtan mükemmel birliğe sahip görünüşte eserler' yapamayacaklarını belirtmekte; 'mimarın geometrik

\footnotetext{
${ }^{53}$ Antikçağ mimarlarının ise düzenlerin kompozisyonunu yaparken aritmetik formüllere bağlı kalarak sayısal ilişkilere oturan tasarımlar yaptıklarına, sadece sayıları düzenleyerek orantılı bir bina inşa ettiklerine işaret etmektedir. Ortaçağ mimarlarının binanın bütün bölümleri ile insan ölçeği arasında oransal bir ilişki kurduğunu anlatmaktadır.
} 
şekillere ya da aritmetiğe başvurmadan armonik bir sistem tasarlamast ve gelişstirmesinin imkansız olduğunu' anlatmaktadır. ${ }^{54}$ Antik çağ üzerine çalışanların kendisi gibi felsefik bir sistem çıkarsamaya hiç çalışmadıklarını; oysaki 'mimarlığın ilkeleri konusunda, inşaat yapma sanatından armoni oluşturmayı amaçlayan büyük yöntemlere varıncaya kadar bizden önce gelenlerden ögrenecek çok şeyimiz olduğunu' kabul etmemiz gerektiğini aşağıdaki sözleriyle de yinelemektedir (Viollet-le-Duc, 2020, s. 29-50).

"Eski devirlerin sanatlarını daha iyi öğrenmeye çalışalım: Yüzyılımızın sanatlarının temellerini bu sanatları sabırla analiz ede ede atacağız; durmadan değişen maddi olguların yanında bir de değişmeyen ilkeler olduğunu kabul edeceğiz; tarih merak uyandırır, ama deşip araştırmayı bilen kişiye, zeki insanin kullanmasi gereken bilgi ve deneyim hazinelerini de sunar. Bunu da kabul edeceğiz"'(s. 50).

Viollet-le-Duc, Dictionaire eserinin 'style' (üslup) maddesinde; 'sanat eserindeki üslup, bir ilkeye dayalı idealin kendini ortaya koymasıdır... Mimar bir sanatçıysa, kendi tasarımını geliştirmek için her tarafta aradı̆̆ bu besini özümser; yok eğer sanatçı değilse, eseri de kökeni hemen, kolayca keşfedilebilen bir alıntı ylğınından öteye geçemez: eserinin üslubu yok demektir....sanatçının üslubu aradığı gün, üslup artık sanatta yer almıyor demektir.... parçalar arasındaki ilişkileri kuran, yani mimarlıkta 'proportion' denilen şeyi kazandıran aklın işe karışmasıdır üslup.... sanatların içlerine sinmiş olan üslupların hangi öğelerden kaynaklandı̆̆ını bulmaya çalışıyoruz. Üslubun bu dünyadaki şeylerin mantıksal düzenine uygun olarak peşinden gidilen bir fikrin, bir ilkenin, özel bir çaba gösterilmeyen, doğal ve güzel bir kokusu olduğuna, tıpk belirli yasalar uyarınca boy atan bitki ile birlikte geliş̧iğine, kendi başlarına iyice yavan oldukları için heybemizden çıkartıp eserlerin üzerine serptiğimiz bir tür baharat olmadiğına herkes ikna olduğunda, işte ancak o gün emin olacă̆ız geleceğin bizlere üslup denileni bahşedeceğine' şeklinde üsluba ilişkin görüşlerini açıklamakta, Ortaçağ mimarlığının, uygulanan strüktür ilkelerinin şaşmaz sonucuna göre biçimlenmiş oldukları için üslup sahibi olduğunu anlatmaktadır (Viollet-le-Duc, 2015, s. 61-96).

Viollet-le-Duc, restorasyonunu yaptığı yapılarda sadece harap kısımları onarmakla kalmayıp, yapıların restitüsyonuna ilişkin yaptı̆̆ 1 araştırmalar doğrultusunda; geç dönem eklerini kaldırarak kendi tasarımları ile yapıları, yukarıda alıntıladığımız şekilde 'iyi' bir üsluba sahip olması perspektifi ile, tamamlamıştır. Nitekim, Viollet-le-Duc'e göre; "Restorasyon kelimesi de restorasyon yapmak da moderndir. Bir yapıyı restore etmek demek, onu korumak, onarmak, veya yeniden yapmak değil, belirli bir zamanda hiç varolmadiğı şekliyle tam bitmiş bir yapı haline getirmek demektir" (Erder, 1972, s. 19).

Viollet-le-Duc'ün sunduğumuz çeşitli örneklerde bu tanıma uygun restorasyonlar yaptığı görülmektedir. Viollet-le-Duc'ün bu tamamlamaları, yapılarda üslup birliği sağlamakta, öte yandan onun, mimari restorasyonu yapının mimari yaratıc1lıkla yeniden inşa edilmesi olarak gördüğünü ortaya koymaktadır. Ona göre bir mimar, yapılarının bütünlügünü sağlamak için heykeltıraş, ressam ve kuyumcuları yöneten Ortaçağın büyük ustaları gibi, diğer sanatçıların işlerini organize eden bir orkestra şefi gibi olmalı sanatın her alanından anlamalıdır. Viollet-le-Duc bu anlayışla restorasyonunu yaptığı yapıların mimari süslemelerini, heykellerini kendisi yapmış, iç mekanlarını düzenlediği yapıların mobilyalarını da kendisi tasarlamıştır. ${ }^{55}$

Viollet-le-Duc'ün yaptığı restorasyonlar yaşadığı dönemden bu yana mimarlık ortamında tartışılan bir konu olmuştur. Araştırmacıların bu konudaki görüşleri iki karşı̂t gurupta toplanabilir. Viollet-le-Duc'ün birçok restorasyonunda tarihi yapılara yaptığı büyük ölçekli tamamlamalarla tarihi

\footnotetext{
${ }^{54}$ Ona göre 'ahenk' 'eşit bölümlemelerin doğrudan görülebilmesinden kaçınmak, ama bunların arasında yine de belirli oranların kurulmasını sağlamakla', yani 'hem orantılı hem de benzemez yanların bulunması' ile mümkündür ve 'orantıların ahenklı olması benzerlik değil, oran gerektirir'.

${ }^{55}$ Mobilya tasarımlarının hepsinde yapım malzemesi olarak parlak meşe ağacı kullanmıştır.
} 
anıtların özgünlük değerinin azaldığını düşünen bir çok uzman vardır (Hitchcock, 1982, s.279-280). Bahsedilen eleştiri doğrultusunda, diğer grup ise, Viollet-le-Duc'ün yaptığı restorasyonlarla tarihi anıtları günümüze kazandırmış olmasının çok daha önemli olduğunu savunmaktadırlar. Viollet-leDuc'ün tarihi yapılarla modern mimarlı̆g 1 birleştirleştirdiği bu restorasyonlarının, bu anlamda mimarlık ve mimari restorasyon tarihinde eşsiz bir değere sahip olduğunu düşünenler de vardır (Murphy, 2000, s. 130).

Viollet-le-Duc'ün bu restorasyon uygulamaları günümüz restorasyon anlayışında da kabul görmemekte ve yapılmaması gereken bir tutuma örnek teşkil etmektedir. Ancak gözardı edilmemelidir ki, onun restorasyonları mimari koruma ve restorasyon tarihinde 19. yüzyılın eşsiz örnekleri olarak tarihi birer belge değeri taşımaktadırlar. Tarihi koruma bilincini ve mimari tasarım yaratıcılığını birleştirdiği bu restorasyonları, bu anlamda özgün eserlerdir. Viollet-le-Duc'ün mimari restorasyon anlayışına ilişkin yazıları ise mimari restorasyon kuramını anlamakta ayrı bir öneme sahiptir.

\section{Restorasyon Kuramı}

Bugün de mimari restorasyon tarihinin ilk kuramcısı olarak kabul edilen Viollet-le-Duc, restorasyon üzerine görüşlerini anlattığı ayrı bir kitap yazmamış ancak bu konudaki görüşlerini Dictionnaire adlı eserinde 'restauration' başlıklı madde altında geniş kapsamlı olarak anlatmıştır. Bunun dışında restorasyon çalışmalarıyla ilgili 50 rapor yazdığı tespit edilmiştir. Paris Notre-Dame Katedrali, Pierrefonds Şatosu, Coucy Şatosu, Carcassone Surları çalışmalarını ise kitap olarak yayınlamıştır. ${ }^{56}$

Orta Doğu Teknik Üniversitesi Mimarlık Fakültesi Mimarlık Bölümü bünyesinde ülkemizin ilk Restorasyon Bölümünü kurmuş olan arkeolog Cevat Erder, 1972'de yayınlanan Restorasyon: Eugène Emmanuel Viollet-le-Duc isimli kitabında Viollet-le-Duc'ün söz konusu eserindeki "restorasyon" maddesini de Türkçeye çevirmiştir. Viollet-le-Duc, Dictionnaire' de çeşitli maddeleri açıklarken, yapılsalcılar gibi "dil”"den örnekler vererek kanıtlar sunmaktadır. Örneğin restorasyon maddesinde Romalıların restorasyon yapmak yerine yeni yapı yaptıklarını bu nedenle Latince'de restorasyon kelimesini karşılayan bir kelime olmadığı söyleyen Viollet-le-Duc "reficere, renovare, instaurare" gibi kelimelerin yeniden kurmak, yenilemek anlamına geldiğine dikkat çekmektedir. Ortaçağ sanatının dilbilgisi kuralları gibi ilkeleri olduğunu, tüm fikirleri ifade edebilecek bir dil gibi, tüm ihtiyaçları karşılayabilecek imkanlar sunduğunu belirtir. Bu nedenle bir Ortaçağ yapısının restorasyonu için Ortaçağın dilinin çok iyi bilinmesi gerektiğine işaret eder (Erder 1972, s. 58).

$\mathrm{Bu}$ restorasyon maddesinde Viollet-le-Duc, bir yapının restorasyonun yapılması için nelere dikkat edileceğini; restorasyon uzmanının hangi özelliklere sahip olması gerektiğini ve restorasyona ilişkin belirlediği kriterleri anlatmıştır. Bir restorasyon uzmanının hem tecrübeli ve becerikli bir mimar, hem de titiz bir arkeolog olması gerektiğini belirtmektedir. Ayrıca, her kentin mimarlığının coğrafi özelliklere uygun, kendine özgü bir üslup ve mimari prensiplerle biçimlenmesi nedeniyle, mimarın mimarlık tarihini iyi bilmesi gerektiğini söylemiştir (Erder, 1972, s. 39-40).

$\mathrm{Bu}$ özelliklere sahip olan mimarın, yapının restorasyonuna başlamadan önce biçimini, strüktürünü, üslubunu, anatomisini, analiz etmesi; her izi değerlendirerek yapının mimari elemanlarını tarihlendirmesi, düşmüş olan parçaların özgün yerlerini tespit etmesi ve yapıyı mimari özelliklerini anlatan rapor, çizim ve fotoğraflarla belgelenmesi gerektiğini belirtmiştir. Ortaçağ yapılarının strüktürünün de antik Roma dönemi yapılarından farklı olarak, her parçanın birbirine yaptığı kuvvetlerin dengesine dayanan bir strüktürle inşa edildiğini, bu nedenle yapılan müdahalelerin yapıya zarar vermemesi için mimarın yapının strüktürel dilini iyi anlaması gerektiğini vurgulamıştır. Mimarın bu analizleri sırasında yapının problemlerini de belirlemesi ve bu problemlere ilişkin birden fazla çözüm üretmesi gerektiğini, böylelikle karşılaşabileceği en kötü

\footnotetext{
${ }^{56}$ Viollet-le-Duc’ün yayın listesi için bkz. (Tosun, 2008, s. 215-228)
} 
durumlarda soğukkanlılıkla ne yapacağını bilecek durumda olacağını anlatmaktadır (Erder, 1972, s.47-50).

Viollet-le-Duc'e göre her yapı yapıldığı dönemin üslup özelliklerine uygun olarak onarılmalı ve tamamlanmalıdır. Ona göre ekler belli bir dönemi ifade ediyorsa ve sağlamsa kaldırılmamalıdır. Ancak daha sonra yapılan ekler ve müdahalelerin ilk dönemden farkını ortaya koyan izler korunmalı ve hatta belirginleştirilmelidir. Eğer geç dönem ekleri harabe durumunda ise yada yapıldığı dönemin karakterini yansıtan özellikler sunmuyorsa, bu ekler kaldırılmalı ve yapı ilk yapıldığı dönemdeki haline göre restore edilmelidir. Ancak bunun için mimarın kendini o yapıyı yapan mimarın yerine koyarak düşünmesi ve o mimarın aynı durumda nasıl davranacağını anlayarak yapıyı tamamlaması gerekmektedir. Böylelikle yapı yaşadığından daha uzun süre gelecek nesillere aktarılabilecektir (Erder, 1972, s. 45-46).

Bir yapıyı korumanın en iyi yolunun ona bir işlev kazandırmak olduğunu belirten Viollet-leDuc, restorasyon uzmanının kendini o yapıyı yapan mimarın yerine koyarak, aynı programı onun nasıl çözeceğini düşünerek, içinde bulunduğu dönemin de olanaklarını kullanarak güzel bir çözüm üretebileceğini; çağın teknolojisinin ve yeni malzemelerin de bu anlamda geniş olanaklar sağlayacağını anlatmaktadır (Erder, 1972, s. 56-57). anlatmıştır;

Viollet-le-Duc restorasyon maddesi altında yaşadığı döneme ilişkin düşüncelerini şöyle

“...tarihi devirlerin başlangıcından bu yana sadece bizim devrimiz, geçmişe karşı alışılmadık bir tavır takınmıştır. Adım adım ileriye yönelişi ve gelişmeleri, insanlığın değişimini takip ederek maziyi çözümlemek, mukayese etmek, sinıflandırmak onun gerçek tarihini ortaya koymak istemiştir." (Erder, 1972, s. 23).

Ayrıca, Fransız yönetimindeki merkeziyetçi tutumun sonucu olarak Paris ve birkaç merkezde hakim olan mimari bilgi, metod ve teknolojik yeniliklerin ülkenin diğer kentlerine ulaşamadığından bahseden Viollet-le-Duc; Ecole des Beaus Arts'da ve Roma'daki Fransız Akademisi'nde eğitim gören mimarların ise sadece antik yapı eğitimi aldıkları için Ortaçağ yapılarını restore edemeyeceklerini, daha da önemlisi hemen hemen hepsinin Paris'ten ve diğer birkaç merkezden dışarı çıkmadığını, bu nedenle Fransa'nın diğer kentlerindeki mimar ihtiyacını karşılayamadıklarını belirtmektedir (Erder, 1972, s. 51-53).

Viollet-le-Duc'ün restorasyon çalışmalarında restorasyona ilişkin kendi görüşlerini uygulamamış olduğu bir çok araştırmacı tarafından belirtmektedir (Pevsner, 1972, s. 213). Murphy, Viollet-le-Duc'ün restorasyon üzerine düşünceleri ile restorasyon uygulamalarının ayrı tutulması gerektiğini, yukarıda bahsedilen restorasyon maddesini (1868-1874); Vézelay'daki Katedral, Paris Notre-Dame Katedrali, Pierrefonds Şatosu, ve St. Denis'deki restorasyonlarından çok sonra yazmış olduğunu belirtmiş ve onun restorasyon düşüncelerinin yaptığı restorasyon çalışmaları sayesinde olgunlaşmış olduğuna işaret etmiştir (2000, s. 13).

Viollet-le-Duc restorasyon çalışmalarında öncelikle yapının geçirdiği tüm dönemleri ve bu dönemlerdeki süreçleri, ardından biçimsel, strüktürel, yapı malzemeleri ve yapı teknolojisi açısından farklılıklarıyla bu dönemlerin mimari özelliklerini ve mimari anlayışlarını belirlemeye çalışmıştır. Onun ortaçağ mimari mirasına ilişkin yapmış olduğu ayrıntılı belgeleme çalışmalarına ve bu yolla edindiği engin bilgi birikimine dayanıyor olması, tespitlerinin bilimsel oldukları kadar doğru olduklarını da düşündürmektedir. Kendisi de bunu şu şekilde ifade eder (1866);

"Gerçek anlamda mimari, medeniyetlerin sadece uygarlikların kiyafetidir, ve bir uygarlık için diyebiliriz ki: Bana mimarisini gösterin, size tarihi çizgisinin ana hatlarını göstereyim." (s. 353) 
Viollet-le-Duc'ün hem mimari mirasa ilişkin yaptığ değerlendirmelerde, hem de mimari koruma kararlarında, Ortaçağ mimari mirasının tasarım yaklaşımında tespit ettiği, belirli bir geometriye temellenen ana prensiplerin yönlendirici olduğu görülmektedir. Tasarımlarını da, St. Gimer örneğinde olduğu gibi, aynı prensiplere temellendirerek, mimaride tarihsel biçimlerin tekrarıyla oluşan tasarımlara karşı, özgün tasarımların yapılabilmesine yönelik bir yöntem öne sürmüştür. Mimari miras ve koruma alanındaki bahsettiğimiz öncü çalışmaları mimariyi okuma ve anlamada yeni bir perspektif sunmaktadır. Mimariyi analiz etme-değerlendirme-koruma ve tasarlama boyutlarını aynı ilkeye temellendiren bütünsel yaklaşımı onu mimarlık tarihi disiplini içinde dikkat çekici ayrı bir yere oturtmaktadır. Sonuç olarak Viollet-le-Duc'ün 'mimari mirası' anlamada, belgelemede, korumada; ve bunların mimarlık eğitimindeki önemini ortaya çıkarmada övgüye değer bahsettiğimiz çalışmalarının, hem kendi hem de kendisinden sonraki dönemlere ilham verici etkilerini bugün de taşımakta olduğu kanısındayız.

\section{Kaynakça}

Akın, G. (2003). Sadece başlamış bir proje olarak: 1908 Romantizmi ve Vedat Tek. M. Vedat Tek: kimliğinin izinde bir mimar, A. Batur (Haz.), Yapı Kredi Yayınları, 21-38.

Arseven, C. E. (1998) Sanat Ansiklopedisi, 5 cilt, ( 1. Bask1 1975). Milli Eğitim Bakanlığı.

Bercé, F., Foucart B. vd. (1987). Viollet-le-Duc: architect, artist, master of historic preservation

Bercé, F. (1996). Viollet-le-Duc, Eugène Emmanuel. The Dictionary Of Art, J. Turner (Ed.), 32, Macmillan Publishers, 594-599.

Bergdoll, B. (1990). The foundations of architecture: selections from the dictionnaire raisonné, Eugène Emmanuel Viollet-le-Duc, K. D. Whitehead (Trans.), George Braziller.

Bressani, M. (1989, december). Notes on the Viollet-le-duc's philosophy of history: dialectics and technology. Journal Of The Society Of Architectural Historians, 48, 327-350.

Bressani, M. (2000a). Viollet-le-Duc's optics. Architecture and the sciences: exchanging metaphors, A. Picon and A. Ponte (Eds.), Princeton Architectural Press, 118-139.

Bressani, M. (2000b, december). Memory and modernity: Viollet-le-Duc at Vézelay, Journal of Society of Architectural Historians, 54 (9), 552.

Boucher-Rivalain, O. (1998). Attitudes to Gothic in French architectural writings of the 1840s. Architectural History, 41, 145-152.

Clark, W. (1989, december). Viollet-le-Duc. Art Journal, 48(4), 356-359.

Damish, H. (1980). Les Entretiens Sur l'Architecture ou du Structuralisme au Fonctionnalisme. Actes Du Colloque International Viollet-le-Duc, Nouvelles Editions Latines, 93-99.

Durant, S. (1980). Nulla sies sine Linea': Viollet-le-Duc's Drawings. A.D. Architectural Design Profile: Viollet-le-Duc, Academy Editions, 30-35.

Eigen, E. (1999, june). l'Imaginaire Scientifique de Viollet-le-Duc; Leon Vaudoyer: Historicism in the Age of Industry. The Journal of Society of Architectural Historians, 58(2), 225-227.

Elliott, S. C. (1986). Frank Lloyd Wright and Viollet-le-Duc: Organic Architecture and Design from 1850-1950, Kelmscott Gallery of Chicago.

Erder, C. (1972). Restorasyon: Eugène Emmanuel Viollet-le-Duc, Orta Doğu Teknik Üniversitesi Mimarlık Fakültesi Yayınları.

Encyclopédie d'Architecture, (1856). Tome Septième, 1, 3-4. 
Encyclopédie d'Architecture, (1856b). Tome Sixième, 8, 135.

Encyclopédie d'Architecture. (1857). Enseignement de l'architecture: un nouveau professeur (mimarlık eğitimi: yeni bir profesör). Tome Septième, 1, 1-3.

Encyclopédie d'Architecture. (1859). Wagons du Train Impérial: Offert à S. M. l'Empereur Par la Compagnie du Chemin de Fer d'Orleans (Orleans Demir Yolları Şirketi Tarafından Ekselansları İmparatora Arz Edilen İmparatorluk Treni Vagonları). Tome Heuvième, 9, 129131.

Encyclopédie d'Architecture. (1861a). Tome Onzième, 4, 64.

Encyclopédie d'Architecture, (1861b). Tome Onzième, 10, 153.

Encyclopédie d'Architecture, Deuxieme Série: Gazette des Architects et Du Batiment, (1863). 16, 222.

Encyclopédie d'Architecture, Deuxieme Série: Gazette des Architects et Du Batiment, (1865). l'Ecole Centrale d'Architecture. 2, 23-26.

Foucart, B.vd. (1980). Viollet-le-Duc, Réunion Des Musées Natonaux.

Géza Hajos, (1980). Relations entre Viollet-le-Duc et l'autriche au XIXème siecle. Actes Du Colloque International Viollet-le-Duc, Nouvelles Editions Latines.

Hearn, M. F. (1995). The architectural theory of Viollet-le-Duc: readings and commentary, Massachusetts Institute of Technology (MIT) Press.

Hitchcock, H.R. (1982). Architecture: nineteenth and twentieth centuries, (Original work published 1958). Pelican.

Jacques, A. (1982). The programmes of the architectural section of the Ecole des Beaux-Arts: 18191914. R. Middleton (Ed.), The Beaux-Arts and the Nineteenth Century French Architecture, (pp. 59-65). Massachusetts Institute of Technology Press.

Jokilehto, J. (1999). A history of architecture conservation, ICCROM.

Levine, N. (1982a) The competition for the Grand Prix in 1824, R. Middleton (Ed.), The Beaux-Arts and The Nineteenth Century French Architecture, (pp. 66-124). MIT Press.

Levine, N. (1982b). The book and the building: Hugo's theory of architecture and Labrouste's Bibliothèque Ste-Geneviève. R. Middleton (Ed.), The Beaux-Arts and The Nineteenth Century French Architecture, (pp.138-174). Massachusetts Institute of Technology Press.

Macclintock, L. (1981, october). Monumentality Versus Suitability: Viollet-le-Duc's Saint Gimer at Carcassonne. Journal of the Society of Architectural Historians, 40 (3), 218-235.

Mead, C. (1983, september,). Jean Baptiste Lassus (1807-1857) and Viollet-le-Duc. Art Bulletin, 65 (3), 523-525.

Melissa. A. (2003). Aristocratic chateau to republican villa: the changing construction of rational theory and regional form in the country houses of Viollet-le-Duc (France), [Doctoral Dissertation, Harvard University].

Middleton, R. (1967). Viollet-le-Duc. Encyclopedia of World Art, XIV, McGraw-Hill Book Company, 800 .

Middleton, R. (1982, july). Jean-Baptiste Lassus, ou le Temps Retrouve des Cathedrales. The Burlington Magazine, 124 (952) Special issue in honour of Terence Hodgkinson, 456-457. 
Middleton, R. (1998, november). l'Imaginaire scientifique de Viollet-le-Duc. The Burlington Magazine, 140 (1148), 764.

Middleton, R. ve D. Watkin. (2003). Architecture of the nineteenth century. (ilk bask1 1980), Electa Architecture.

Murphy, K. (2000). Memory and modernity: Viollet-le-Duc at Vézelay. Pennsylvania University Press.

Packard, R T. and Wilkes J. A. (1989). Viollet-le-Duc, Eugène Emmanuel. Encyclopedia of Architecture: Design, Engineering and Construction, (5, pp.253-254), John Wiley\&Sons.

Pevsner, N. (1969). Ruskin and Viollet-le-Duc: Englishness and Frenchness in the appreciation of Gothic architecture, Thames and Hudson.

Pevsner, N. (1972). Some architectural writers of the nineteenth century, Clarendon Press.

Savarenskaia, T. F. (1980). Le livre de Viollet-le-Duc: l'art Russe. Actes du colloque international Viollet-le-Duc, Nouvelles Editions Latines, 251-263.

Summerson, J. (1963). Viollet-le-Duc and the rational point of view. Heavenly mansions and other essays on architecture, (Original work published 1949). 135-158.

Togay, H. (1980). Viollet-le-Duc (1814-1879) üzerine bir etüd. Arkitekt, sayı 379, 108-112.

Togay, H. (1980). Viollet-le-Duc üzerine bir etüd (1814-1879). Arkitekt, sayı 380, 152-155.

Tosun, Ç. B. (2008). Eugène Emmanuel Viollet-le-Duc (1814-1879) ve etkileri, [Yayınlanmamış Doktora Tezi, Hacettepe Üniversitesi]. Sosyal Bilimler Enstitüsü Sanat Tarihi Anabilim Dal1.

Van Zanten, D. (1994). Building Paris: architectural institutions and the transformation of the French capital, 1830-1870, Cambridge University Press.

Viollet-le-Duc, E. E. (1846). Le sytle Gothique au XIX siècle, Les Annales Archéologiques, 2, 333 353.

Viollet-le-Duc, E. E. (1854-1868). Dictionnaire raisonné de l'architecture Française du XI au XVI Siècle, 9 cilt ve index, Bance.

Viollet-le-Duc, E. E. (1856a). Excursion en Allemagne (8). Encyclopédie d'Architecture, Tome Sixième, 3,43 .

Viollet-le-Duc, E. E. (1856b). Excursion en Allemagne (11). Encyclopédie d'Architecture, Tome Sixième, $9,141$.

Viollet-le-Duc, E. E. (1856c). Mon cher confrere: la reforme de l'enseignement officiel de l'architecture (sevgili meslektasim: mimarligin egitimi üzerine resmi reform). Encyclopédie d'Architecture, (20 Aral1k 1855 tarihli mektup), Tome Sixième, 1, 4-11.

Viollet-le-Duc, E. E. (1857). Description du Château de Pierrefonds, B.Bance

Viollet-le-Duc, E. E. (1858-1875). Dictionnaire raisonné du mobilier français, de l'epoque. Carlovingienne à la Renaissance (Karolenj Dönemi’nden Rönesans’a Kadar Fransız Mobilyalarının Açıklamalı Sözlüğ̈̈). 6 cilt., B. Bance.

Viollet-le-Duc, E. E. (1863). Décret du 13 Novembre 1863: Réponse à M. Beulé secrétaire perpétuel de l’Académie des Beaux-Arts (1) (13 Kasım 1963 Kararnamesi: Güzel Sanatlar Akademisi 
daimi sekreteri M.Beulé'ye cevap). Encyclopédie d'Architecture, Deuxieme Série: Gazette des Architects et Du Batiment, no 16, 213.

Viollet-le-Du,c E. E. (1866). l'Architecture dans ses rapports avec l'histoire: conférence à la Sorbonne du 4 Février 1867. (4 Subat 1867'de Sorbonne'daki konferans:tarihle ilişki olarak mimarlık). Encyclopédie d'Architecture, Deuxième Série: Gazette des Architectes et Du Batiment, no 23, 353.

Viollet-le-Duc, E. E. (1987). Lectures on architecture. B. Bucknall (Çev.), 2 cilt, Dover Publications.

Viollet-le-Duc, E. E. (1863). Histoire d'une maison, J. Hetzel ve Cie.

Viollet-le-Duc, E. E. (1863). Entretiens sur l'architecture, 1, A.Morel.

Viollet-le-Duc, E. E. (1874). Histoire d'une forteresse, J. Hetzel ve Cie.

Viollet-le-Duc, E. E. (1875). Histoire de l'habitation humaine, J. Hetzel ve Cie.

Viollet-le-Duc, E. E. (1877). Histoire d'un hôtel de ville et d'une cathédrale, J. Hetzel et Cie.

Viollet-le-Duc, E. E. (1879). Histoire d'un dessinateur : comment on apprand à dessiner, J. Hetzel et Cie.

Viollet-le-Duc, E. E. (2015). Mimarlık ve Üslup. (A. Tümertekin vd., Çev). Eugène Emmanuel Viollet-le-Duc 19. yüzyılda Gotik üslup üzerine. (s. 61-101) içinde. Janus Yayıncılık. (Reprinted from Style. Dictionnaire raisonné de l'architecture Française du XI au XVI Siècle, VIII, (s. 477-501) içinde. 1854-1868, Bance-Morel)

Viollet-le-Duc, E. E. (2019). Paris Notre-Dame Katedrali restorasyon projesi: Adalet ve İbadet Bakanı'na sunulan rapor. (A. Tümertekin vd., Çev).Restorasyon üzerine: Eugène Emmanuel Viollet-le-Duc . (s. 17-77) içinde. Janus Yayınc1l1k. (Reprinted from Projet de restauration de Notre-Dame de Paris: rapport adressé á M. le Ministre de la Justice et des Cultes, annexe au projet de restauration remis le 31 janvier 1843.)

Viollet-le-Duc, E. E. (2020). Orantı. (A. Tümertekin vd., Çev). Mimarlıkta orantı. (s. 11-50) içinde. Janus Yayincilik. (Reprinted from Proportion. Dictionnaire raisonné de l'architecture Française du XI au XVI Siècle, VII, 1854-1868, Bance-Morel)

Viollet-le-Duc, E. L. (1902). Lettres inédites de Viollet-le-Duc recueillies et annotées par son fils.

Viollet-le-Duc, G. (1980a). Eléments Biographiques. Viollet-le-Duc, B. Foucart vd. (Eds.), Réunion des Musées Natonaux.

Viollet-le-Duc, G. (1980b). An interview with Geneviève Viollet-le-Duc. A.D. Architectural Design Profile: Viollet-le-Duc, Academy Editions, 15-18.

İnternet Kaynakları

La Vedette. (2021 Aralık, 14). photo.rmn.fr (photo by D. Jean-Eugène) https://www.photo.rmn.fr/archive/14-553169-2C6NU0AGBUIR4.html

La Vedette. (2021 Aralık, 14). are.na (Chicago architecture biennial) https://www.are.na/block/1090404

La basilique Saint-Sernin. (2021 Aralık, 14). saintraymond.toulouse.fr https://saintraymond.toulouse.fr/attachment/508075/ 